\title{
Activity and Stability of Dispersed Multi Metallic Pt-based Catalysts for CO Tolerance in Proton Exchange Membrane Fuel Cell Anodes
}

\author{
AYAZ HASSAN and EDSON A. TICIANELLI \\ Instituto de Química de São Carlos-USP, Avenida Trabalhador São Carlense, 400, Parque \\ Arnold Schimidt, Caixa Postal 780, 13560-970 São Carlos, SP, Brazil
}

Manuscript received on July 21, 2017; accepted for publication on September 6, 2017

\begin{abstract}
Studies aiming at improving the activity and stability of dispersed $\mathrm{W}$ and Mo containing Pt catalysts for the $\mathrm{CO}$ tolerance in proton exchange membrane fuel cell (PEMFC) anodes are revised for the following catalyst systems: (1) a carbon supported PtMo electrocatalyst submitted to heat treatments; (2) Pt and PtMo nanoparticles deposited on carbon-supported molybdenum carbides $\left(\mathrm{Mo}_{2} \mathrm{C} / \mathrm{C}\right) ;(3)$ ternary and quaternary materials formed by $\mathrm{PtMoFe} / \mathrm{C}, \mathrm{PtMoRu} / \mathrm{C}$ and $\mathrm{PtMoRuFe} / \mathrm{C}$ and; (4) $\mathrm{Pt}$ nanoparticles supported on tungsten carbide/carbon catalysts and its parallel evaluation with carbon supported PtW catalyst. The heattreated $\left(600^{\circ} \mathrm{C}\right) \mathrm{Pt}-\mathrm{Mo} / \mathrm{C}$ catalyst showed higher hydrogen oxidation activity in the absence and in the presence of $\mathrm{CO}$ and better stability, compared to all other Mo-containing catalysts. PtMoRuFe, PtMoFe, PtMoRu supported on carbon and $\mathrm{Pt}$ supported on $\mathrm{Mo}_{2} \mathrm{C} / \mathrm{C}$ exhibited similar $\mathrm{CO}$ tolerances but better stability, as compared to as-prepared PtMo supported on carbon. Among the tungsten-based catalysts, tungsten carbide supported Pt catalyst showed reasonable performance and reliable stability in comparison to simple carbon supported PtW catalyst, though an uneven level of catalytic activity towards $\mathrm{H}_{2}$ oxidation in presence of $\mathrm{CO}$ is observed for the former as compared to Mo containing catalyst. However, a small dissolution of $\mathrm{Mo}, \mathrm{Ru}, \mathrm{Fe}$ and $\mathrm{W}$ from the anodes and their migration toward cathodes during the cell operation is observed. These results indicate that the fuel cell performance and stability has been improved but not yet totally resolved.
\end{abstract}

Key words: Heat treatment, $\mathrm{CO}$ tolerance, stability, carbides, quaternary catalysts.

\section{INTRODUCTION}

Nowadays different varieties of fuel cells are in use for different applications, but the proton exchange membrane fuel cells (PEMFCs) have gained considerable attention among them due to

Correspondence to: Edson Antonio Ticianelli

E-mail: edsont@iqsc.usp.br

* Contribution to the centenary of the Brazilian Academy of Sciences. characteristics properties, such as low operating temperature, high power density, high efficiency in energy conversion etc. Among these PEMFCs, the fuel cell that operates with hydrogen in the anode and oxygen/air in the cathode is the most efficient one (Peighambardoust et al. 2010). Pt is the most active metal for these reactions (Ralph and Hogarth 2002), but an expensive metal, therefore various attempts have been made to use its reduced amount 
in the electrodes by alloying with other transition metals and supporting the resultant composites on substrates with high surface area, such as carbon black (Antolini 2009).

Due to the very low anode overpotential of the hydrogen oxidation reaction (HOR) on $\mathrm{Pt}$, particularly in acid media, $\mathrm{H}_{2}$ is supposed to be the best fuel, which can be used in the anode of PEMFC for obtaining sufficient high performance in these cells, but unfortunately the use of pure $\mathrm{H}_{2}$ in these system is highly unfavorable due to the lack of required infrastructure for its production. In order to overcome this problem, some alternative methods have been proposed such as the reforming of fuels such as methanol, ethanol or natural gas, allowing $\mathrm{H}_{2}$ to be obtained in situ or on board, resulting in the formation of a gas mixture of composition with $75 \% \mathrm{H}_{2}, 25 \%$ $\mathrm{CO}_{2}$ and 1-2\% CO (Baschuk and Li 2003). The $\mathrm{CO}$ concentration in the resultant gas mixture can be further reduced through succeeding clean up steps to sufficient low levels (10-100 ppm), even such a low concentration of $\mathrm{CO}$ in the anode feed stream can poison the Pt catalyst deployed in the anode. This blocks the active sites of the electrocatalyst available for $\mathrm{H}_{2}$ chemisorption and subsequent electro-oxidation, considerably decreasing the catalyst activity, especially in $1 \mathrm{ow}$ temperatures operation systems $\left(70-150^{\circ} \mathrm{C}\right)$ (Manasilp and Gulari 2002, Urian et al. 2003, Wee and Lee 2006, Ticianelli et al. 2005). Therefore, $\mathrm{CO}$ poisoning is of fundamental concern in the PEMFCs anode and hence a major fence in the large scale commercialization of PEMFC systems. Several methods have been reported in the literature for overcoming the $\mathrm{CO}$ poisoning effect, the most common being the physicochemical changes in $\mathrm{Pt}$ electrocatalyst by adding a second or third transition metal or with the formation of oxide or carbide phase employing as the catalyst support (Chung et al. 2007, Leng et al. 2002).
In general, the catalysts employed in $\mathrm{H}_{2} /$ $\mathrm{O}_{2}$ fuel cell anodes are largely composed of nanoparticles of PtM bimetals (where $\mathrm{M}=$ transition metal), such as PtMo, PtRu, PtW, PtRh, etc. (Hassan et al. 2014a, Lee et al. 2005, Pereira et al. 2006, 2009, Santiago et al. 2003), with the PtMo giving the best catalytic performance, when the PEMFC single cell anode is supplied with $\mathrm{H}_{2}$ containing $\mathrm{CO}$. Other more recently investigated materials are $\mathrm{Pt}_{3} \mathrm{Co}, \mathrm{Pt} / \mathrm{FeOx}$ and $\mathrm{Pt} / \mathrm{BeO}$ (Liu et al. 2016, Kwon et al. 2016, Zhang et al. 2017). Earliest works involving the use of PtMo alloys were made in the end of the 1990 by Grgur et al. (1997, 1998). They used well-characterized $\mathrm{Pt}_{\mathrm{x}} \mathrm{Mo}$ $(100-\mathrm{x})(\mathrm{x}=70$ and 75$)$ bulk alloys and rotating disk electrode for investigating the hydrogen oxidation reaction in the presence of $\mathrm{CO}$. In these works, it was observed that the existence of Mo atoms along side Pt on the surface of the catalyst results in an enhancement of $\mathrm{H}_{2}$ oxidation caused by the oxidative decrease of the adsorbed CO coverage on Pt. Researches were also conducted involving testing of carbon-supported PtMo nanocrystals in liquid electrolyte (Grgur et al. 1999) and in single PEMFC under operational conditions (Mukerjee et al. 1999). Here, a two-to-three fold enhancement of $\mathrm{CO}$ tolerance in the PEMFC is reported for a $\mathrm{PtMo} / \mathrm{C}$ catalyst (Pt:Mo atomic ratio of $87: 13$ ), compared to PtRu/C. On the other hand, theoretical calculations had shown that in cubo-octahedrical PtMo nanoparticles (Wang et al. 2005), the Pt atoms weakly segregate to the particle surface forming core-shell nanostructures with the shell enriched by $5-14 \% \mathrm{Pt}$, compared to the bulk composition. Nowadays, it is generally accepted that the association between $\mathrm{Pt}$ and a second metal improves the electrocatalytic activity, because it allows the catalyst to perform the oxidative removal of adsorbed CO. Also, these bimetallic catalysts have further been modified either with a third or fourth element for the purpose of improvements in the activity and stability. More recently, it has 
been found that the addition of $\mathrm{Ru}$ and/or Fe to the $\mathrm{PtMo} / \mathrm{C}$ catalyst leads to an improvement in the activity towards $\mathrm{H}_{2}$ oxidation in the presence of $\mathrm{CO}$ as well as in the stability of the resultant catalysts (Hassan et al. 2014c). In subsequent work it has been shown that the addition of Au nanopartilces to the lattice of PtRu catalyst causes a decrease in the onset potential for methanol oxidation in addition to the gain in stability up to 10,000 voltammetric cycles. In comparison to the overpotential increase of $20 \mathrm{mV}$ for carbon supported PtRu catalyst, quite small increase was observed for $\mathrm{Au}$ modified PtRu catalyst (Li et al. 2010, Liang et al. 2008).

Usually, these bimetallic or trimetallic nanopartilces are supported on some high surface area substrate, the latter being considered an integral part of the resultant catalyst. The interaction between the metal particles and the support modify the electrocatalytic activity of the catalyst with respect to bulk metal, which occurs most probably through a chemical bond, which can consequently change the catalytic, chemisorptive properties and kinetic parameters of the catalyst for a given reaction. For example, it has been shown that the kinetic parameters of certain catalytic systems may be affected by the particular support used (Hoffmann et al. 2001). Tauster et al. (1978) introduced the concept of strong metal support interaction (SMSI) and observed that some of the metal particles from Group VIII supported on $\mathrm{TiO}_{2}$ and other reducible oxides lose their chemisorptive properties towards $\mathrm{H}_{2}$ and $\mathrm{CO}$, when they are reduced at temperature higher than $773 \mathrm{~K}$. Besides, it has been shown that the electron transfer from the oxygen atom present on the support to the metal particle can enhance the electron density and hence the catalytic activity (Triantafillou et al. 1995, Watwe et al. 1998). In addition, a model based on a study made by extended X-ray absorption spectroscopy (EXAFS), $\mathrm{X}$-ray photoelectron spectroscopy (XPS) and fourier transform infra-red spectroscopy (FTIR) has shown that due to metal-support interaction, a change in the energy position of the metal valence orbital takes place, a factor which affect the catalytic activity (Koningsberger et al. 2000, Miller et al. 2000). Besides, the charge transfer process between the metal particles and the support can cause significant modification in their catalytic properties. A quantitative aspect of metal-support interaction in term of charge transfer process at the metal support interface has been studied through theoretical calculations (Lemire and Meyer 2004), which provide useful information regarding the nature of chemical bonds at the surface, magnitude of charge transfer at the metal-support interface and its effect on the strength of adsorption bonds. It is apparent that the metal-support interaction is of fundamental importance for the enhanced catalytic activity of the metal support ensemble. The exact nature and mechanism of this interaction depends upon the particular catalytic system, including the support material, nature of active component, size and shape of metal particles along others.

Keeping this in view, an important issue in the area of fuel cell research is based on the development of new carbon and non-carbon supports, which could enhance not only the catalytic activity but the durability of the fuel cell catalysts, the last one being of fundamental importance in the corrosive fuel cell environment and very critical for the development of new substrates. However, carbon, the most widely used support material in the fuel cell catalysis is unstable under strong oxidizing conditions, thus leading to the poor stability of the catalyst during long time of operation. Therefore, more recently the trend of using carbon black as support material has been changed to the development of novel carbon and non-carbon material, aiming to improve the catalytic activity and stability of the resultant catalysts. For example, it has been shown that the graphitized carbon and carbon nanotubes (CNTs) are more proficient fuel cell catalyst supports as compared to conventional carbon black for the fuel cell catalysis (Auer et 
al. 1998). Similarly, it has been reported that the catalyst based on $\mathrm{WO}_{3}$ support exhibits extremely higher electrochemical stability than commercial Vulcan XC-72 carbon (Dou et al. 2012).

Some further works deal with the evaluation of other non-carbon supported catalysts in the methanol oxidation and oxygen reduction reactions (Lu et al. 2006, Joo et al. 2008). These studies reported a superior catalytic performance and greater stability for tungsten carbide, molybdenum carbide and molybdenum oxide towards MOR and ORR as compared to commercial carbon supported Pt catalyst. In addition to these reactions, these materials have excellent catalytic activity for hydrogen oxidation reaction (HOR), particularly in the presence of $\mathrm{CO}$. For instance, it has been shown that only a voltage loss of $120 \mathrm{mV}$ at $1 \mathrm{Acm}^{-}$ 2 of current density was observed for Pt supported on $\mathrm{Mo}_{2} \mathrm{C} / \mathrm{C}$ as compared to voltage loss of $150 \mathrm{mV}$ for carbon supported PtMo and more than $300 \mathrm{mV}$ loss for carbon supported Pt catalyst, when the anode feed stream was changed from pure $\mathrm{H}_{2}$ to $\mathrm{H}_{2}$ containing 100 ppm CO (Hassan et al. 2014b). Similarly, Hassan et al. (2015) reported that mono tungsten carbide supported Pt catalyst prepared by a simple impregnation method not only showed an improved electrocatalytic activity towards HOR in the presence of $\mathrm{CO}$, but also showed an enhance durability when subjected to long term stability test. The advantage of using carbide as support material is that they usually lead to the stabilization of small metal particles, thus giving unique properties to the resulting catalytic system, which arises from the synergistic effect between the ad-metal and the carbide substrate. These carbide substrates can be produced by simple carburization method with high surface areas and good electrical conductivity and catalytic properties similar to platinum group metals (Pt, Pd, Ir, Rh, Ru) (Chen 1996, Ham and Lee 2009).

In this review, recent investigations aiming at improving the electrocatalytic activity for the
$\mathrm{HOR}$ in the presence of $\mathrm{CO}$ as contaminant, and the stability of different materials formed by $\mathrm{Pt}$ and Pt-M (where $\mathrm{M}=\mathrm{Mo}, \mathrm{W}$ ) supported on carbon and carbide materials are revised. Experimental approaches considered are: (1) application of a heat treatment at various temperatures ranging from 400 to $700{ }^{\circ} \mathrm{C}$ to carbon supported PtMo (60:40, Pt:Mo) electrocatalyst; (2) deposition of $\mathrm{Pt}$ and PtMo nanoparticles on carbon-supported molybdenum carbides $\left(\mathrm{Mo}_{2} \mathrm{C} / \mathrm{C}\right)$; (3) employing ternary and quaternary materials formed by $\mathrm{PtMoFe} / \mathrm{C}, \mathrm{PtMoRu} / \mathrm{C}$ and $\mathrm{PtMoRuFe} / \mathrm{C}$; (4) deposition of $\mathrm{Pt}$ on carbon-supported tungsten carbide in comparison to a carbon supported PtW catalyst.

\section{MATERIALS AND METHODS}

\section{CATALYST PREPARATION AND PHYSICAL CHARACTERIZATION}

The effective dispersion of the catalyst nanoparticles on the support material depends upon the method, which is used for the preparation, and the nature of the support material itself. Different methods, such as formic acid, formaldehyde, sodium borohydride, polyol, hydrazine, ethylene glycol, microwave assisted methods etc. are used for the deposition and dispersion of the nanoparticles on support materials (Santiago et al. 2004, Lebedeva and Janssen 2005, Zhang et al. 2010, Cao et al. 2016, Wojcieszak et al. 2006, Kim et al. 2006). It has been reported that the electrocatalytic activity of carbon supported Pt catalyst prepared by various method decreases in the order: formic acid $>$ sodium borohydride $>$ hydrazine (Chen et al. 2004). Though, the preparation method plays a key role in dispersion and distribution of metal nanoparticles on the support material, the effect of the nature of the support material in affecting their catalytic properties cannot be totally ignored (Zhang et al. 2004). The support may play either a direct or indirect role in affecting the catalytic 
properties of the metal support system (Aricò et al. 1990). The direct role involves a bi-functional type of mechanism, in which the main function is provided by the dispersed metal particles and side function is provided by the support material. Alternatively, the catalytic action may occur at the interface between the metal particles and the support, which is greatly defined by the support. The indirect role may involve the influence of support on the dispersion and morphology of metal particles, their surface and bulk properties and also their resistance to sintering and poisoning.

Here, the most common approach employed for the incorporations of the metallic particles on the substrate refers to the formic acid reduction method. Among the materials involved in this investigation, a $\mathrm{Pt}_{60} \mathrm{Mo}_{40} / \mathrm{C}$ catalyst was prepared by the said method (Santiago et al. 2003), which involves mixing of carbon powder in to $0.3 \mathrm{M}$ formic acid solution. After the mixture is dispersed in the ultrasonic bath, it is then heated slowly to $80{ }^{\circ} \mathrm{C}$. The solutions of the precursor salts are then added drop wise to the heated mixture and after leaving for about half hour, it is filtered, washed with copious amount of de-ionized water and then dried at $90{ }^{\circ} \mathrm{C}$ for two hours to get the desired catalyst, which was named as PtMo/C. Different samples of this catalyst were taken, placed in the tubular furnace and subjected to heat treatment at different temperature ranging from 400 to 700 ${ }^{\circ} \mathrm{C}$ under reducing $\mathrm{H}_{2}$ atmosphere for $1 \mathrm{~h}$. The purpose of the heat treatment was to reduce any oxygen containing species present on the surface of the catalyst, aiming to obtain a true bimetallic alloy catalyst. The same procedure was repeated to prepare $\mathrm{Pt}_{60} \mathrm{~W}_{40} / \mathrm{C}$ catalyst with 20 wt. \% metal contents. $\mathrm{Pt} / \mathrm{C}$ with 20 wt. \% metal loading was obtained commercially from E-Tek.

The molybdenum and tungsten carbides supported on carbon $\left(\mathrm{Mo}_{2} \mathrm{C} / \mathrm{C}\right.$ and $\left.\mathrm{WC} / \mathrm{C}\right)$ with 30 wt. $\% \mathrm{MC} / \mathrm{C}$ (where $\mathrm{M}=\mathrm{Mo}$ or $\mathrm{W}$ ) were prepared by high intensity sonication process and simple impregnation methods, respectively. The details of these methods can be found elsewhere (Suslick et al. 1996, Hyeon et al. 1996). Briefly, a slurry of molybdenum hexacarbonyl $\left(\mathrm{Mo}(\mathrm{CO})_{6}\right.$, Aldrich) and carbon powder (Vulcan XC-72R) in hexadecane was sonicated with a high intensity ultrasonic horn at $90{ }^{\circ} \mathrm{C}$ for $3 \mathrm{~h}$. The resulting mixture was filtered, washed several times with purified pentane and heated at $90{ }^{\circ} \mathrm{C}$ until a black powder was obtained. This powder was transferred to a tubular quartz reactor and placed in a furnace. It was then exposed to an argon flow at $100{ }^{\circ} \mathrm{C}$ during $1 \mathrm{~h}$. The argon was then replaced by a $1: 1 \mathrm{CH}_{4} / \mathrm{H}_{2}$ mixture and the temperature was increased at a rate of 5 ${ }^{\circ} \mathrm{C}$ min $^{-1}$, firstly until $300{ }^{\circ} \mathrm{C}$ for $1 \mathrm{~h}$, next until 400 ${ }^{\circ} \mathrm{C}$ also for $1 \mathrm{~h}$ and finally until $500{ }^{\circ} \mathrm{C}$ for $12 \mathrm{~h}$, in order to carburize the black powder and obtain the molybdenum carbide. The tungsten carbide support was prepared by a simple impregnation method, using tungsten hexachloride (WCl6, Aldrich) and carbon powder. The mixture was then heated at 70 ${ }^{\circ} \mathrm{C}$, until the ethanol was evaporated completely and finally heat treated under $\mathrm{CH}_{4} / \mathrm{H}_{2}$ atmosphere at $800{ }^{\circ} \mathrm{C}$ for $3 \mathrm{~h}$. After that, during the cooling, the mixture went through a passivation process, in which the atmosphere was $99 \%$ argon and $1 \%$ $\mathrm{O}_{2}$ for $12 \mathrm{~h}$ to give the carbon supported tungsten carbide (WC/C). Deposition of Pt on the resultant carbide supports was also made through formic acid method as explained previously. Several different catalytic systems, including $\mathrm{PtMo} / \mathrm{C}, \mathrm{PtMo} / \mathrm{C}$-heat treated, $\mathrm{PtW} / \mathrm{C}, \mathrm{Pt} / \mathrm{Mo}_{2} \mathrm{C} / \mathrm{C}, \mathrm{Pt} / \mathrm{WC} / \mathrm{C}, \mathrm{PtMoRu} / \mathrm{C}$, $\mathrm{PtMoFe} / \mathrm{C}, \mathrm{PtMoRuFe} / \mathrm{C}$ and $\mathrm{Pt} / \mathrm{C}$ have been investigated and the results have been compared among those with the best performance.

Different characterization techniques such as EDX was used to determine the metal content of $\mathrm{Mo} 2 \mathrm{C} / \mathrm{C}, \mathrm{WC} / \mathrm{C}$, metal loading ( $\mathrm{Pt}, \mathrm{Mo}$ and $\mathrm{W}$ ) and Pt:Mo, Pt:W atomic ratio. A scanning electron microscope LEO, 440 SEM-EDX system (LeicaZeiss, DSM-960) with a microanalyser (Link analytical QX 2000) and a Si (Li) detector a $20 \mathrm{keV}$ 
incident electron beam was used for this purpose. In this work crystallite size and lattice parameters, were determined by X-ray diffraction (XRD, RIGAKU model RU200B) in the $2 \theta$ range from 10 to $90^{\circ}$ and using $\mathrm{CuK} \alpha$ radiation. Simple TEM analysis of various catalysts was carried out in order to know about the particle sizes of the catalysts as well as their size distribution. These analyses were performed, using Transmission electron microscopy (TEM, JOEL 2100 transmission electron microscope).

Some illustrative results of elemental analyses as obtained by EDX are given in Table I. The Mo and $\mathrm{W}$ contents for $\mathrm{Mo}_{2} \mathrm{C} / \mathrm{C}(30 \mathrm{wt}$. \%) and $\mathrm{WC} / \mathrm{C}$ (30 wt. \%) supports are found to be 19 and $19.3 \mathrm{wt}$. $\%$, respectively, which indicates that the real metal carbide contents are smaller than these values and the rest are metal oxides or just carbon. These support materials suffer from a further reduction in the Mo and $\mathrm{W}$ contents after deposition of the Pt, which may be due to dissolution of some Mo and W species during the synthesis. The measured $\mathrm{Pt}$ metal loading of the resultant $\mathrm{Pt} / \mathrm{Mo}_{2} \mathrm{C} / \mathrm{C}$ and $\mathrm{Pt} / \mathrm{WC} / \mathrm{C}$ catalysts after Pt deposition is 16 and 16.8 wt. \%, respectively, which is somewhat smaller than the target value of 20 wt. \% but still reasonable for evaluating catalytic activity. Similarly, the metal loading $(\mathrm{Pt}+\mathrm{Mo}$ or $\mathrm{Pt}+\mathrm{W})$ of 16 and 19 wt. \% were obtained for PtMo/C and $\mathrm{PtW} / \mathrm{C}$ catalysts, respectively. The reduction in the metal contents of these catalysts may be due to the partial dissolution of these metals i.e Pt and Mo during the deposition process.

Figure 1 presents powder X-ray diffractograms of the carbide supports considered here, and the carbide and carbon supported catalysts. The peaks for both $\alpha$ and $\beta$ phases of $\mathrm{Mo}_{2} \mathrm{C}$ are observed in the XRD pattern of $\mathrm{Mo}_{2} \mathrm{C} / \mathrm{C}$ (Schaidle et al. 2012), whereas the pattern of $\mathrm{WC} / \mathrm{C}$ exhibits the diffraction peaks corresponding to hexagonal planes of WC (JCPDS 65-2888). After the addition of Pt to these supports, most of the carbide peaks disappeared and the resultant $\mathrm{Pt} / \mathrm{Mo}_{2} \mathrm{C} / \mathrm{C}$ and $\mathrm{Pt} / \mathrm{WC} / \mathrm{C}$ catalysts show essentially the diffraction peaks corresponding to (111), (200), (220), (311) and (222) crystal planes of $\mathrm{Pt}$ in addition to weaker reflection at some angles of the WC phase just for $\mathrm{Pt} / \mathrm{WC} / \mathrm{C}$. In the case of $\mathrm{Pt} / \mathrm{Mo}_{2} \mathrm{C} / \mathrm{C}$, the peaks of the carbide phase can't be seen anymore after the addition of $\mathrm{Pt}$, which is consistent with the previously reported data (Pang et al. 2010). The XRD patterns of PtMo, PtW and Pt supported on carbon catalysts only shows the peaks corresponding to the crystalline structure of $\mathrm{Pt}$, indicating the absence of any other segregated phase of Mo and W. The average crystallite sizes of the nanoparticles calculated from the corresponding XRD patterns are included in Table I. Almost no inclusion of Mo and $\mathrm{W}$ in the Pt crystallites is observed in all cases but particularly in the case of $\mathrm{PtMo} / \mathrm{C}$ and $\mathrm{PtW} / \mathrm{C}$ catalysts, as indicated by the values of lattice parameters. In fact, these results seem to indicate that most of the carbide phase has been oxidized during the $\mathrm{Pt}$ deposition, resulting in nanocrystalline/amorphous oxides, whose features could not be evidenced by the XRD data.

Typical TEM images and the corresponding histograms are shown for $\mathrm{PtMo} / \mathrm{C}, \mathrm{Pt} / \mathrm{Mo}_{2} \mathrm{C} / \mathrm{C}, \mathrm{Pt} /$ $\mathrm{WC} / \mathrm{C}$ and $\mathrm{PtW} / \mathrm{C}$ catalysts in Figure 2. Several different regions of the same TEM image were used for collecting and counting 200 particles for

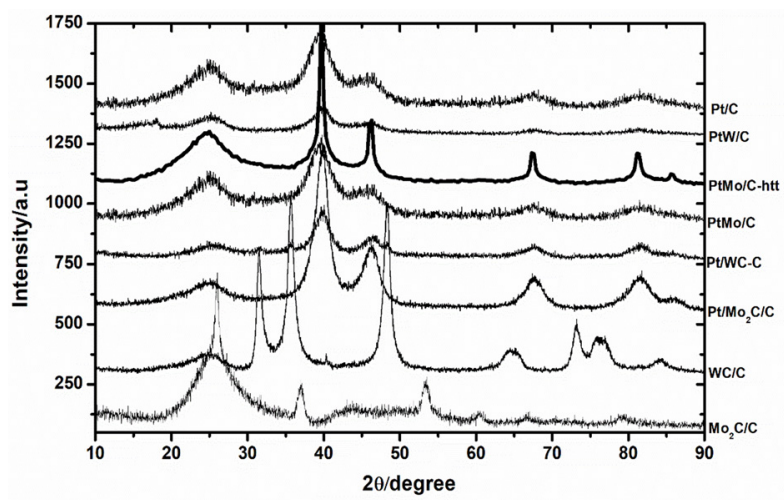

Figure 1 - XRD patterns of carbon supported molybdenum carbide and tungsten carbide $\left(\mathrm{Mo}_{2} \mathrm{C} / \mathrm{C}\right.$ and $\left.\mathrm{WC} / \mathrm{C}\right)$ supports, Pt supported on these carbide supports, PtMo-heat treated and PtMo-as prepared supported on carbon catalysts. 
TABLE I

Elemental compositions, crystallite/diameter sizes and lattice parameters of various electrocatalysts.

\begin{tabular}{ccccccc}
\hline & \multicolumn{2}{c}{ Element (wt.\%) determined by EDX } & Crystallite/Particle size (nm) & $\begin{array}{c}\text { Lattice constant } \\
\left(\mathbf{A}^{\circ}\right) \mathbf{X R D}\end{array}$ \\
\cline { 2 - 7 } Support/Electrocatalysts & $\mathbf{P t}$ & $\mathbf{M o} / \mathbf{W}$ & $\mathbf{C}$ & XRD & TEM & \\
\hline $\mathrm{Mo}_{2} \mathrm{C} / \mathrm{C} 30$ & $\mathrm{NA}$ & 19.0 & 81.0 & $\mathrm{NA}$ & $\mathrm{NA}$ & $\mathrm{NA}$ \\
$\mathrm{WC} / \mathrm{C} 30$ & $\mathrm{NA}$ & 19.3 & 80.7 & $\mathrm{NA}$ & $\mathrm{NA}$ & $\mathrm{NA}$ \\
$\mathrm{Pt} / \mathrm{Mo}_{2} \mathrm{C} / \mathrm{C} 30$ & 16.1 & 12.1 & 71.8 & 3.0 & 2.3 & 0.392 \\
$\mathrm{Pt} / \mathrm{WC} / \mathrm{C} 30$ & 16.8 & 16.0 & 67.2 & 2.9 & 3.2 & 0.391 \\
$\mathrm{PtMo} / \mathrm{C}$ & 13.3 & 3.0 & 83.7 & 2.4 & 2.3 & 0.391 \\
$\mathrm{PtW} / \mathrm{C}$ & 11.8 & 7.2 & 81.0 & 2.3 & 2.2 & 0.391 \\
\hline
\end{tabular}

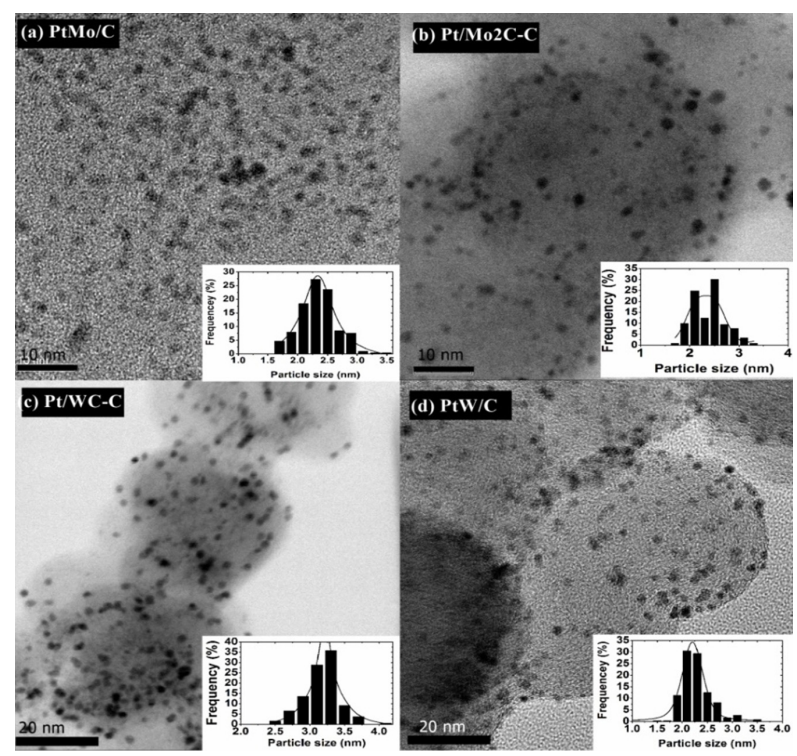

Figure 2 - TEM images of different anode catalysts; insets: corresponding histograms based on collection of 200 particles.

calculating histograms shown in insets. As can be seen from the TEM images, tungsten/molybdenum carbide and carbon black supports present different surface morphology, the latter apparently being more porous. A uniform dispersion of the Pt metal particles is evidenced for all catalysts, as can be seen in the images and histograms. The average Pt particle sizes measured from these images are included in Table I, where the values are quite consistent to average crystallite sizes calculated from the XRD patterns and have been observed for all catalysts.
The XPS spectra has been recorded in the Pt and $\mathrm{W} 4 \mathrm{f}$ region for the carbon supported $\mathrm{PtW}$ catalyst as shown in Figures 3a and 3b, respectively. In the $\mathrm{Pt} 4 \mathrm{f}$ region, three pairs of doublets can be seen, which indicates the change of oxidation states of $\mathrm{Pt}$ form 0 to 2 and then to 4 , corresponding to the existence of different species of $\mathrm{Pt}$, such as $\mathrm{PtO}$ and $\mathrm{PtO}_{2}$. The binding energies of the first set of doublet (71.24 and $74.54 \mathrm{eV}$ ) are the same as that of $\mathrm{Pt}$ in $\mathrm{Pt} / \mathrm{C}$, meaning that no alloy formation take place between $\mathrm{Pt}$ and W. For the other two doublets an increase in the binding energies values to 72.06 and $75.36 \mathrm{eV}$ for the $2^{\text {nd }}$ doublet and 73.48 and $76.78 \mathrm{eV}$ for the $3^{\text {rd }}$ doublet suggest that oxides species have been formed in the Pt catalyst. In the $\mathrm{W} 4 \mathrm{f}$ region two set of doublet was recorded with the binding energies of 35.67 and $37.82 \mathrm{eV}$ and 35.01 and $37.19 \mathrm{eV}$ and are allocated to $\mathrm{WO}_{3}$ and $\mathrm{WO}_{2}$ species, respectively, which indicates that at the Pt-W catalyst surface most of the particles are present in the oxides form. In summary, these bimetallic carbon supported catalysts are mostly present in the oxides form on the surface of the catalysts instead of alloy, which is usually expected but difficult to obtained. These surface oxides species though are useful sometimes in improving the catalyst activity, they lead to the deterioration of the catalyst stability. 

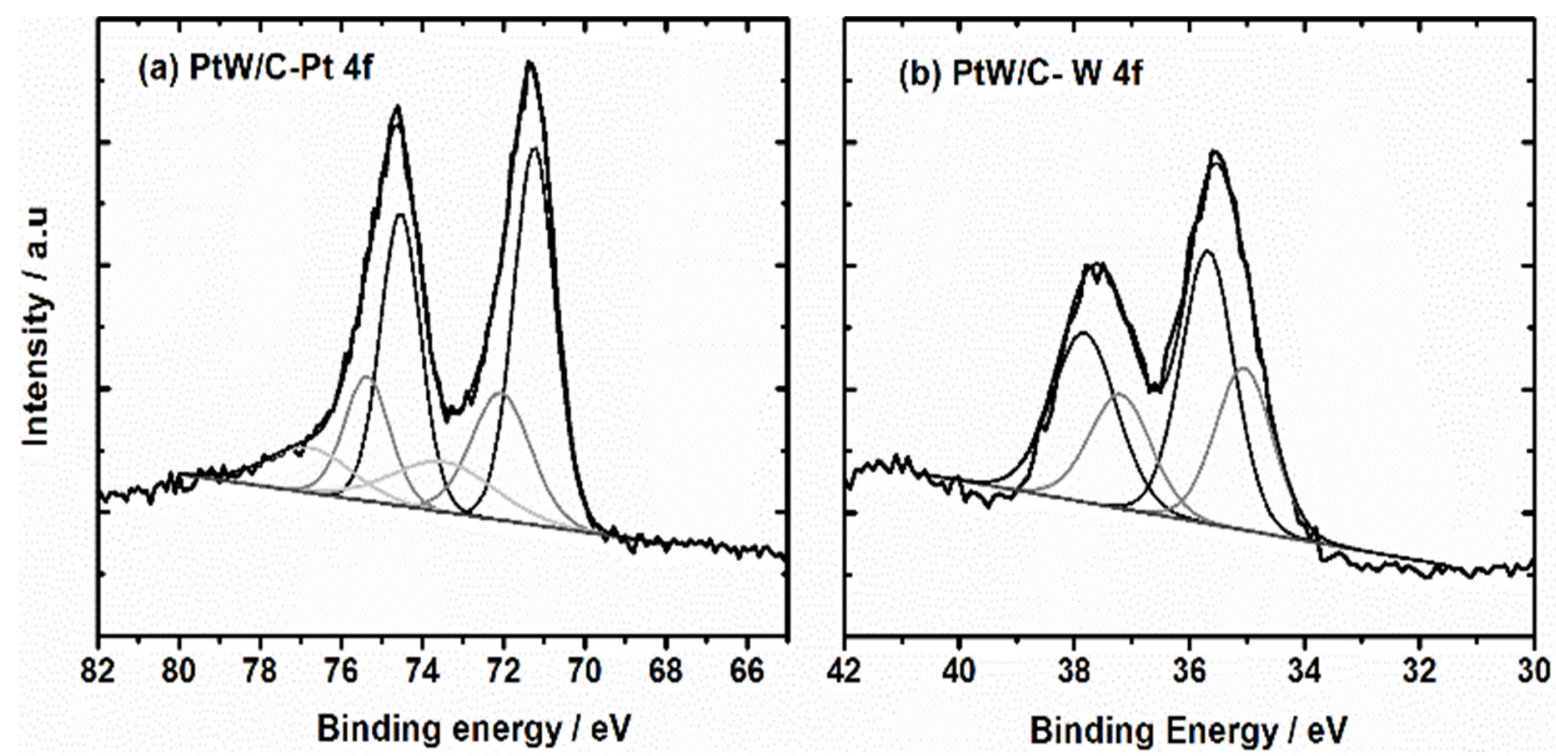

Figure 3 - X-ray photoelectron spectroscopic spectra of carbon supported the PtW/C catalyst in the Pt 4f region (a) and W $4 \mathrm{f}$ regions (b). (Reprinted with permission from Hassan et al. 2015).

\section{ELECTROCHEMICAL INVESTIGATIONS}

Electrochemical investigations has been carried out on unitized proton exchange membrane fuel cells (PEMFC) comprising a pair of gas diffusion electrodes (GDEs) hot-pressed to the proton exchange membrane. These GDEs consist of a gas diffusion layer (GDL) and a catalyst layer CL) supported on a carbon cloth (Cindrellaa et al. 2009). The GDL is prepared by mixing carbon powder and polytetrafluoroethylene at $3 \mathrm{mg} \mathrm{cm}^{-2}$ loading on both sides of carbon cloth. The CL is formed by applying an homogeneous suspension of Nafion ${ }^{\circledR}$ solution, the electrocatalysts $(\mathrm{Pt} / \mathrm{C},(\mathrm{PtMo} / \mathrm{C}$-as prepared, $\mathrm{PtMo} / \mathrm{C}$-heat treated, etc.) and isopropanol is applied on GDL using a brushing procedure in the case of anodes. The same procedure is applied for the cathodes, but this time only with $\mathrm{Pt} / \mathrm{C}$ catalyst. In both cases the metal load is maintained at 0.4 $\mathrm{mg} \mathrm{cm}{ }^{-2}$ with the geometric area of the electrodes keeping at $5 \mathrm{~cm}^{2}$. The quantity of Nafion ${ }^{\circledR}$ used is 35.5 wt. $\%$ of total mass of catalyst layer.

In the case of quaternary catalysts, the conventional brushing technique was also applied, where a layer by layer painting was made by applying a suspension of $\mathrm{PtMo} / \mathrm{C}$ catalyst first to the GDL, followed by $\mathrm{PtRu} / \mathrm{C}$ and finally by $\mathrm{PtFe} / \mathrm{C}$ catalysts. Among the three different kinds of metals ( $\mathrm{Mo}, \mathrm{Ru}$ and $\mathrm{Fe}$ ), the Mo-containing catalyst promotes the WGR (see below), which potentially reduces the $\mathrm{CO}$ content in the gas phase. In this way, the $\mathrm{PtMo} / \mathrm{C}$ layer was placed in the gas entrance in the catalyst layer (Hassan et al. 2014c). On the other hand, $\mathrm{PtFe} / \mathrm{C}$ is supposedly more stable than the other materials, and so it was place in contact with the (acid) membrane (Antolini 2016). The resultant catalysts systems contained a total Pt load of $0.4 \mathrm{mg} \mathrm{cm}^{-2}$, equally distributed in the three layers.

Membrane electrode assembly (MEA) has been prepared by compressing the anode and cathode together with electrolyte membrane (Nafion ${ }^{\circledR} 115$, Dupont) between them at $125{ }^{\circ} \mathrm{C}$ for $2 \mathrm{~min}$. The single cell assembly is then formed by placing the MEA between the two graphite plates having channels for distribution of gases. This system is then attached to the aluminum plates on the two sides, which serves as current collectors. Finally, the resultant single cell is mounted in the fuel cell 
station, which controls the various parameters such as flow and humidification of reactant gases, the temperatures of anode and cathode, pressure, cell potential etc.

Figure 4 shows current voltage curves obtained galvanostatically for the single cell assembly, where the cell temperature is kept at $85{ }^{\circ} \mathrm{C}$ and the anode and cathode temperatures are maintained at 90 and $100{ }^{\circ} \mathrm{C}$, respectively, whereas the anode and cathode gas pressures are kept at 1.7 and $2 \mathrm{~atm}$ according to the corresponding temperatures. The system is first kept at a fixed potential of $0.7 \mathrm{~V}$ in pure $\mathrm{H}_{2}$, for $2 \mathrm{~h}$, and then at $0.8 \mathrm{~V}$ in $\mathrm{H}_{2} / 100 \mathrm{ppm}$ $\mathrm{CO}$ also for $2 \mathrm{~h}$, to reach the steady state before the data acquisition. In these experiments, the cathode is continuously fed with $\mathrm{O}_{2}$ saturated with water.

These results are shown for the single cell with freshly prepared $\mathrm{PtMo} / \mathrm{C}, \mathrm{PtMo} / \mathrm{C}$-heat treated, $\mathrm{Pt} /$ $\mathrm{Mo}_{2} \mathrm{C} / \mathrm{C}, \mathrm{Pt} / \mathrm{WC} / \mathrm{C}, \mathrm{PtW} / \mathrm{C}, \mathrm{Pt} / \mathrm{C}$ and $\mathrm{PtMoRuFe} / \mathrm{C}$ anodes, supplied with pure $\mathrm{H}_{2}$ and $\mathrm{H}_{2}$ containing 100 ppm CO, using $\mathrm{Pt} / \mathrm{C}$ cathodes supplied with $\mathrm{O}_{2}$. As can be seen in Figure $4 \mathrm{a}$, the cell fed with pure $\mathrm{H}_{2}$ and with $\mathrm{Pt} / \mathrm{C}$ anode showed the highest activity (highest cell potentials), followed by those with carbon supported PtMo and PtMo-heat treated catalysts. The cells with $\mathrm{Pt} / \mathrm{WC} / \mathrm{C}$ and $\mathrm{PtW} / \mathrm{C}$ anode catalysts show comparatively the same performance, but somewhat smaller than those with PtMo-based anodes. Finally, when the Pt/ $\mathrm{Mo}_{2} \mathrm{C} / \mathrm{C}$ and $\mathrm{PtMoRuFe} / \mathrm{C}$ catalysts are placed in the anode and fed with pure $\mathrm{H}_{2}$, a further decline in cell activity compared to the other anodes is observed.

The patterns of results obtained are totally different, when the anode feed stream is changed to $\mathrm{H}_{2} / \mathrm{CO}$ mixture, as can be observed in Figure $4 \mathrm{~b}$. Here, the cell with $\mathrm{Pt} / \mathrm{C}$ anode shows the lowest current density, as extensively seen previously ( $\mathrm{Li}$ et al. 2003), indicating that the Pt actives sites are easily blocked by the $\mathrm{CO}$ molecules, giving no space for $\mathrm{H}_{2}$ adsorption and thus resulting in the poor catalytic performance for the HOR in this catalyst. The $\mathrm{CO}$ tolerance ability of other catalysts can be further compared through the values of anode overpotential introduced by the presence of CO $\left(\eta_{\mathrm{CO}}\right)$. These $\eta_{\mathrm{CO}}$ values have been obtained by calculating the difference of the cell potentials at a current density of $1 \mathrm{Acm}^{-2}$ in the presence of pure $\mathrm{H}_{2}$ and $\mathrm{H}_{2} / \mathrm{CO}$ mixture. The $\eta_{\mathrm{CO}}$ values of $100,150,120,378,398$ and $159 \mathrm{mV}$ for $1 \mathrm{Acm}^{-}$ ${ }^{2}$ are obtained for $\mathrm{PtMo} / \mathrm{C}, \mathrm{PtMo} / \mathrm{C}$-heat treated, $\mathrm{Pt} / \mathrm{Mo}_{2} \mathrm{C} / \mathrm{C}, \mathrm{Pt} / \mathrm{WC} / \mathrm{C}, \mathrm{PtW} / \mathrm{C}$ and $\mathrm{PtMoRuFe} / \mathrm{C}$ catalysts, respectively. As mentioned before, due to acute poisoning of the carbon supported Pt catalyst by $\mathrm{CO}$, the current density does not reach $1 \mathrm{Acm}^{-2}$.

These polarization results clearly show that Mo and $\mathrm{W}$ containing catalysts present considerably higher activity when subjected to $\mathrm{CO}$ poisoning than $\mathrm{Pt} / \mathrm{C}$, with the PtMo/C-heat treated $\left(600{ }^{\circ} \mathrm{C}\right)$ giving the maximum activity. Following this, a decrease in the performance of the other catalysts is observed in the order: $\mathrm{PtMo} / \mathrm{C}$-as prepared $>$ $\mathrm{PtMoRuFe} / \mathrm{C}>\mathrm{Pt} / \mathrm{Mo}_{2} \mathrm{C} / \mathrm{C}>\mathrm{Pt} / \mathrm{WC} / \mathrm{C}>\mathrm{PtW} / \mathrm{C}$ on the bases of the $\eta_{\mathrm{CO}}$ values obtained above.

\section{UNRAVELING THE CO TOLERANCE MECHANISM}

The CO tolerance of different kind of catalysts is usually elucidated by two distinctive mechanisms: the well know bifunctional and electronic mechanisms. It has been observed that in the bifuntional type of mechanism the existence of ad-metal disseminates the electro-oxidation of $\mathrm{CO}$ to $\mathrm{CO}_{2}$ after the $\mathrm{OH}$-species are spill over on the oxophilic sites prevailed on the second metal to the Pt-CO (Lopes et al. 2010). Whereas, in the electronic effect (Pereira et al. 2006, 2009) it is postulated that the presence of the second metal make changes to the $\mathrm{Pt}$ properties for the $\mathrm{H}_{2}$ and $\mathrm{CO}$ chemisorptions, reducing the $\mathrm{CO}$ coverage and leaving more free Pt sites available for the $\mathrm{H}_{2}$ oxidation.

Santiago et al. $(2003,2004)$ proposed that in the case of Pt-Mo catalysts an enhancement in the 


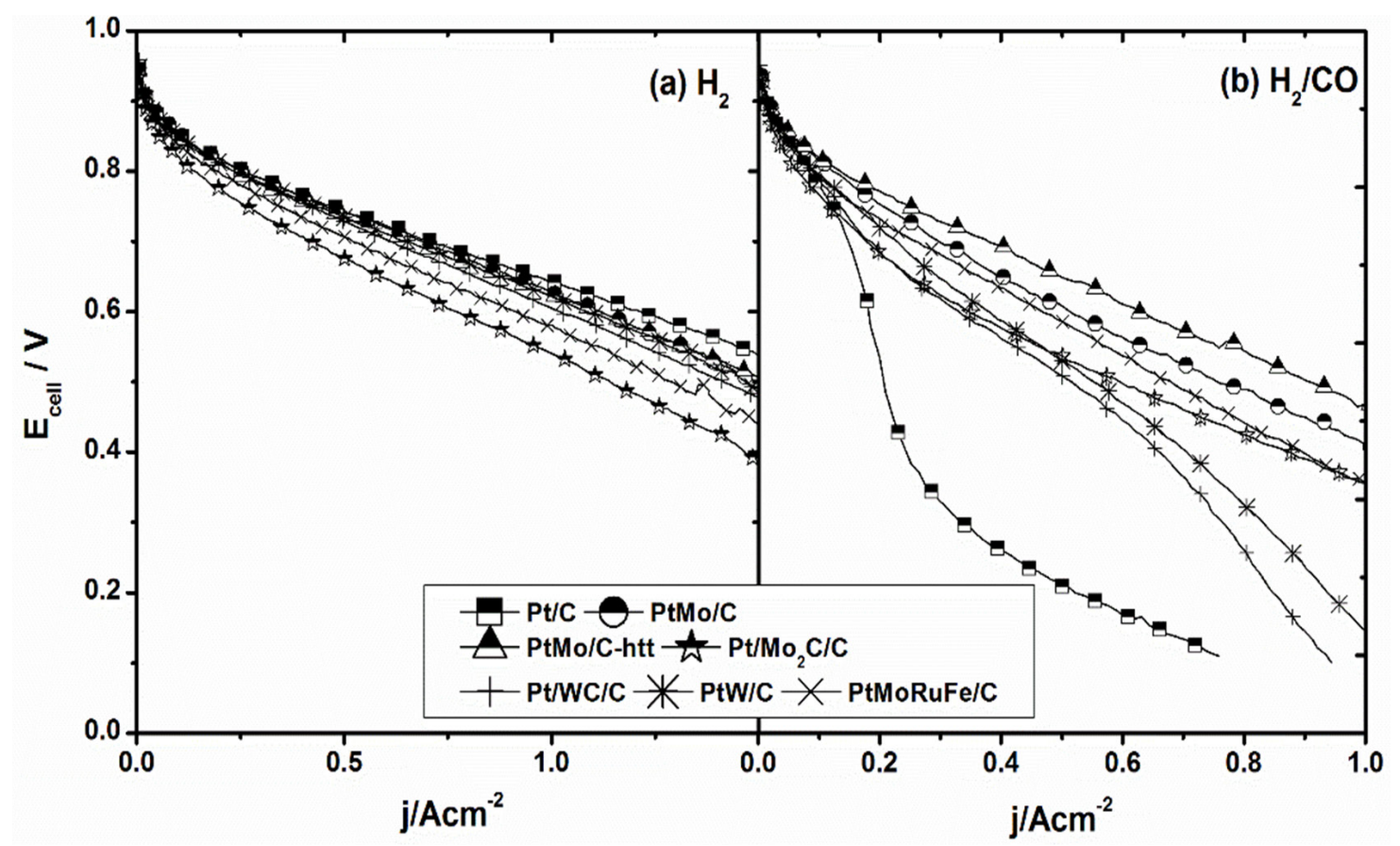

Figure 4 - Single fuel cell voltage-current density curves obtained at cell temperature of $85^{\circ} \mathrm{C}$. The anodes Pt, PtMo, PtMo-heat treated $\left(600^{\circ} \mathrm{C}\right)$ supported on carbon, Pt supported on carbides, and carbon supported PtW and PtMoRuFe catalysts were supplied with (a) pure $\mathrm{H}_{2}$ and (b) $\mathrm{H}_{2} / \mathrm{CO}$ mixture and the carbon supported Pt cathodes were feed with $\mathrm{O}_{2}$.

$\mathrm{CO}$ tolerance is basically achieved by the removal of $\mathrm{CO}$ through a chemical reaction catalyzed at the Mo sites, i.e., the well-known water gas shift reaction (WGSR),

$\mathrm{CO}+\mathrm{H}_{2} \mathrm{O}_{\text {ads }} \rightarrow \mathrm{CO}_{2}+\mathrm{H}_{2}, \Delta \mathrm{G}_{298 \mathrm{~K}}^{\circ}=-28.51 \mathrm{~kJ} \mathrm{~mol}^{-1}$

where $\mathrm{CO}$ is converted to $\mathrm{CO}_{2}$ without direct involvements of protons and electrons. In this reaction, $\mathrm{H}_{2} \mathrm{O}_{\text {ads }}$ represents an activated water molecule probably adsorbed on Mo sites.

Several approaches have been employed to investigate the mechanism of $\mathrm{CO}$ tolerance by different types of electrocatalysts and these include: (1) X-ray absorption spectroscopy in the near edge region (XANES); (2) On line mass spectrometry (OLMS); (3) CO stripping measurements (COst). XANES measurements are essential to determine the affinity of the Pt surface to $\mathrm{CO}$, which is defined by the influence of neighboring atoms on the Pt 5 $\mathrm{d}$ band (the electronic effect), and quite important to understand the degree of CO coverage. OLMS and COst are used to follow the $\mathrm{CO}$ oxidation by the catalyst with formation of $\mathrm{CO}_{2}$, as a function of the electrode potential, and this is fundamental to characterize occurrence of the bifunctional and WGS mechanisms.

As an example, Figure 5 shows XANES spectra, recorded for different catalysts (carbon supported Pt, PtMo and molybdenum carbide supported PtMo catalysts) at the $\mathrm{Pt} \mathrm{L}_{\mathrm{III}}$ edge prior the $\mathrm{CO}$ adsorption and then after $\mathrm{CO}$ was adsorbed at an electrode potential of $50 \mathrm{mV}$ vs.RHE. In the XANES spectra recorded under $\mathrm{H}_{2}$ atmosphere (see the inset of Fig. 5a), quite consistent results are seen for the Pt and PtMo supported on carbon catalysts (Nepel et al. 2013, Mukerjee at al. 2004, Garcia et al. 2008), for which a small increase in the intensity of the white line at ca. $5.0 \mathrm{eV}$ is noticed as compared to $\mathrm{Pt} / \mathrm{C}$. This increase in the magnitude of the white line is really very small but it is caused 
by the presence of second metal/species (in this case by $\mathrm{Mo}$ or $\mathrm{Mo}_{2} \mathrm{C}$ ) near to the $\mathrm{Pt}$ atoms, which prompt a small increase in the $5 \mathrm{~d}$ band vacancies of the latter. As can be seen in Figure $5 \mathrm{~b}$ a more significant increase is noticed in the peak intensities after the $\mathrm{CO}$ adsorption to the surface of the $\mathrm{Pt}$ in all catalysts, and this is assigned to the electron back donation from Pt to adsorbed CO. Since smaller peak intensity is observed in the presence of $\mathrm{H}_{2}$ for $\mathrm{Pt} / \mathrm{C}$ as compared to other catalysts, but the same peak intensities are observed for all the catalysts after $\mathrm{CO}$ adsorption, it is concluded that the $\mathrm{CO}$ poisoning is more severe for $\mathrm{Pt} / \mathrm{C}$ as compared to the Mo-based catalysts.

CO stripping voltammetry has been employed to investigate the adsorbed $\mathrm{CO}$ oxidation processes. Here, the results for $\mathrm{PtMo} / \mathrm{C}, \mathrm{Pt} / \mathrm{Mo}_{2} \mathrm{C} / \mathrm{C}, \mathrm{Pt} /$ $\mathrm{WC} / \mathrm{C}, \mathrm{PtW} / \mathrm{C}$ and $\mathrm{Pt} / \mathrm{C}$ at 25 and $85{ }^{\circ} \mathrm{C}$ are shown in Figure 6. For these experiments the anode (working electrode) is constantly fed with $\mathrm{Ar} / 1000$ ppm CO, while the cathode, used as both reference and counter electrode and is continuously fed with hydrogen. Results in Figure 6 was obtained after $\mathrm{CO}$ was adsorbed on the anode for 30 minutes at a constant potential of 100 and $50 \mathrm{mV}$ for 25 and 85 ${ }^{\circ} \mathrm{C}$, respectively and finally the anode was flushed with Ar for another 30 minutes.

As can be seen in Figure $6 \mathrm{a}$, at $25^{\circ} \mathrm{C}$, the lowest onset stripping values $(0.381$ and $0.50 \mathrm{~V}$, respectively) are recorded for $\mathrm{PtMoRuFe} / \mathrm{C}$ and $\mathrm{PtMo} / \mathrm{C}$, following the trends of the polarization curves in the reverse way, that is, the highest $\mathrm{CO}$ tolerance was observed first for $\mathrm{PtMo} / \mathrm{C}$ and then for $\mathrm{PtMoRuFe} / \mathrm{C}$. The lower $\mathrm{CO}$ stripping potential of the $\mathrm{PtMoRuFe} / \mathrm{C}$ catalyst is caused by the presence of $\mathrm{Ru}$ and $\mathrm{Fe}$, is in agreement with previously reported data (Russell et al. 2007), where $\mathrm{CO}$ oxidation peak potential of $\mathrm{PtRu} / \mathrm{C}$ is reported to occur at a lower potential in comparison to $\mathrm{PtMo} / \mathrm{C}$ catalyst. The $\mathrm{CO}$ stripping onset is seen at almost the same potential for carbon supported $\mathrm{Pt}$ and PtW catalysts, consistently with their poorest

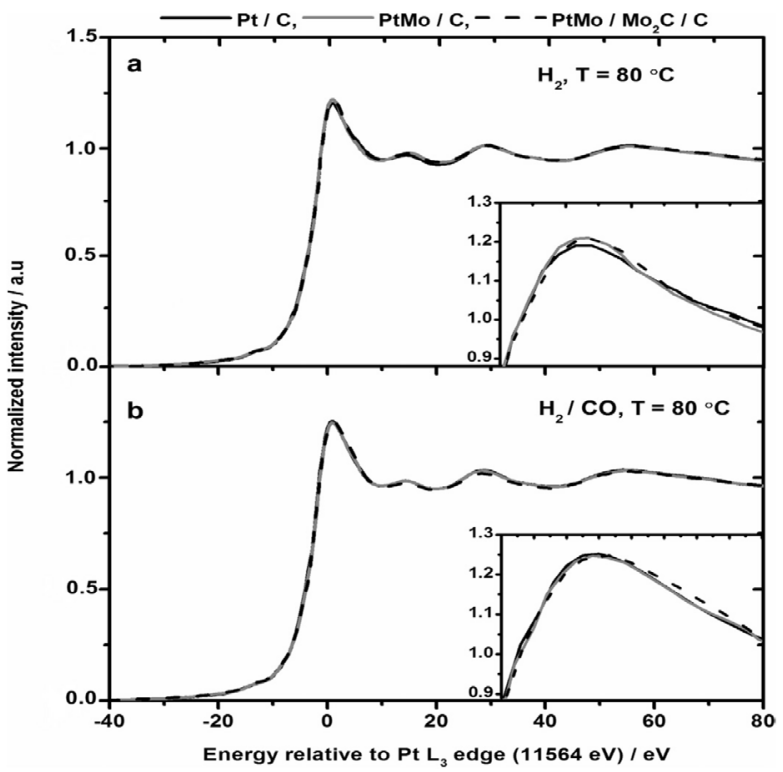

Figure 5 - X-ray absorption spectra at the $\mathrm{Pt} \mathrm{L}_{\mathrm{IJ}}$ edge for carbon supported Pt, PtMo and molybdenum carbide supported PtMo catalysts subjected to: (a) $\mathrm{H}_{2}$ and (b) $\mathrm{H}_{2} / \mathrm{CO}$. Cell temperature at $80^{\circ} \mathrm{C}$. (Reprinted with permission from Hassan et al. 2014b).

$\mathrm{CO}$ tolerance. For the $\mathrm{Pt} / \mathrm{WC} / \mathrm{C}$ catalyst the $\mathrm{CO}$ stripping onset potentials locate at an intermediate potential (ca. $0.56 \mathrm{~V}$ ), is in agreement with its intermediate behavior towards the $\mathrm{CO}$ poisoning denoted by the polarization results.

Higher values of currents resulted from $\mathrm{CO}$ oxidation for $\mathrm{Pt} / \mathrm{C}$ and $\mathrm{PtW} / \mathrm{C}$ catalysts is most probably due to a greater coverage of $\mathrm{CO}$ adsorbed on the surface of these catalysts, whereas for other materials the fractions of the surfaces covered by $\mathrm{CO}$ may be comparatively smaller. This might be because part of $\mathrm{CO}$ is oxidized directly to $\mathrm{CO}_{2}$ by these catalysts following, for example, the chemical step given by the WGSR (Patt et al. 2000, Weigert et al. 2010, Schaidle et al. 2010, Guillen et al. 2002). For PtMo/C and $\mathrm{Pt} / \mathrm{Mo}_{2} \mathrm{C} / \mathrm{C}$ the $\mathrm{CO}$ stripping results are uniform with the data presented in the literature, where a negative shift of about $65 \mathrm{mV}$ was observed vs RHE relative to $\mathrm{Pt} / \mathrm{C}$ (Ham and Lee 2009). When the cell temperature is increased from 25 to $85^{\circ} \mathrm{C}$, all the catalysts seem to be more active towards $\mathrm{CO}$ 


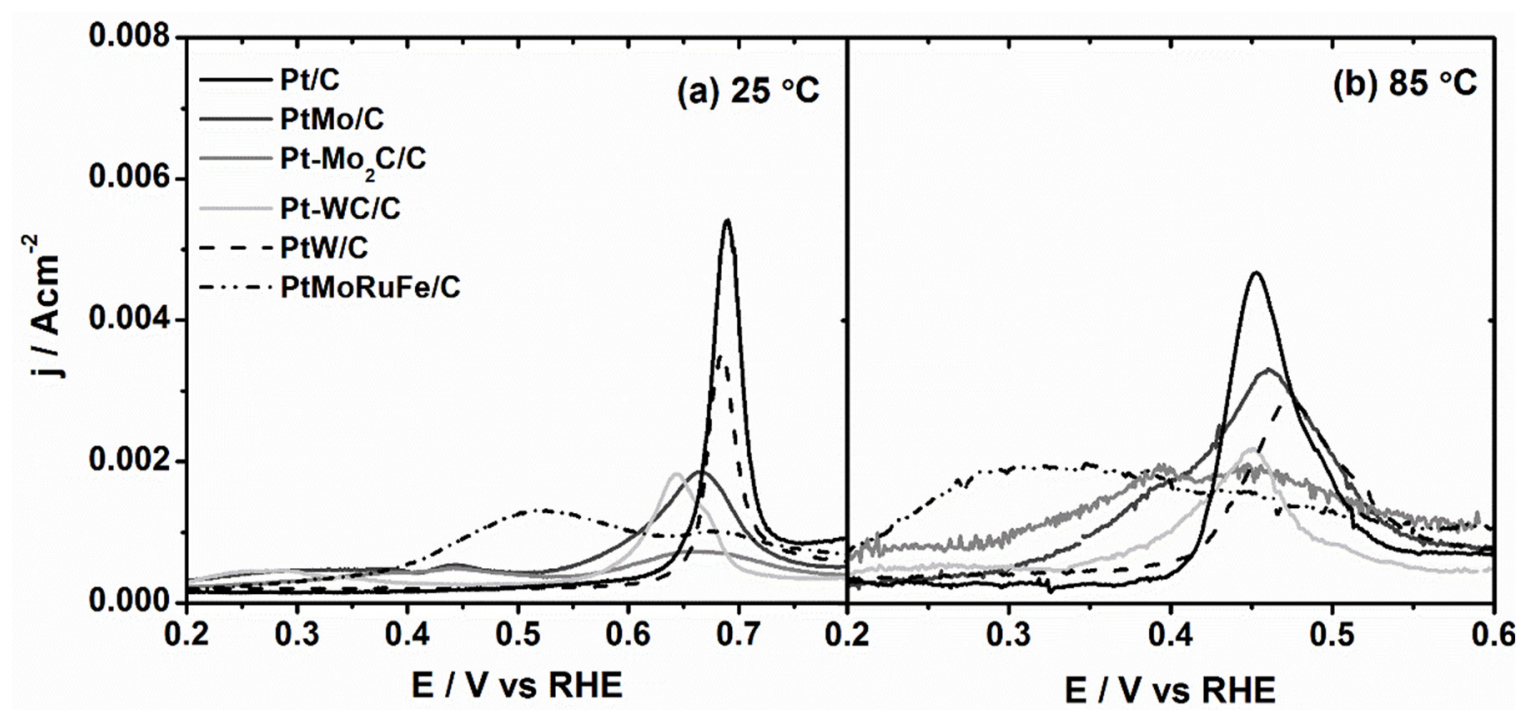

Figure 6 - $\mathrm{CO}$ stripping voltammograms for different anodic catalysts at $25^{\circ} \mathrm{C}$ (a) and $85^{\circ} \mathrm{C}(\mathbf{b})$.

oxidation and hence a negative shift in the stripping peaks is observed. Similar to lower temperature, at higher temperature, the $\mathrm{PtMoRuFe} / \mathrm{C}, \mathrm{PtMo} / \mathrm{C}$ and $\mathrm{Pt} / \mathrm{Mo}_{2} \mathrm{C} / \mathrm{C}$ show the lowest stripping peak potential, $\mathrm{Pt} / \mathrm{C}$ and $\mathrm{PtW} / \mathrm{C}$ show the highest, whereas $\mathrm{Pt} /$ $\mathrm{WC} / \mathrm{C}$ show intermediate peak potentials. These results are consistent with the polarization curves and anode overpotential values, as seen previously.

Online mass spectrometry (OLMS) analyses for $\mathrm{CO}_{2}$ detection at the anode outlet have also been conducted to follow the adsorbed $\mathrm{CO}$ oxidation on the electrocatalyst surface. Figure 7 shows these results for some of the Mo-containing catalysts obtained by intermittently supplying the electrodes with pure $\mathrm{H}_{2}$ and then with $\mathrm{H}_{2}$ containing 1000 ppm $\mathrm{CO}$ with the cell maintained at open circuit. It is seen that production of $\mathrm{CO}_{2}$ occurs when $\mathrm{H}_{2} /$ $\mathrm{CO}$ mixture is injected to the anode for the $\mathrm{PtMo} / \mathrm{C}$ and $\mathrm{Pt} / \mathrm{Mo}_{2} \mathrm{C} / \mathrm{C}$ catalysts (Figs. $7 \mathrm{a}$ and $7 \mathrm{~b}$ ), which confirms the $\mathrm{CO}$ oxidation through a WGSR on the catalyst surface (Ordóñez et al. 2005). Though the extents of the $\mathrm{CO}_{2}$ ionic currents seem different, but this might be due to fluctuation of the spectrometer response. For $\mathrm{PtMoRuFe} / \mathrm{C}$ a similar reaction has been observed, when it is subjected to intermittent $\mathrm{H}_{2}$ and $\mathrm{H}_{2} / \mathrm{CO}$ supply (22). Conversely, for the $\mathrm{Pt} /$
$\mathrm{WC} / \mathrm{C}$ and $\mathrm{PtW} / \mathrm{C}$ catalysts (Figs. 7c and $7 \mathrm{~d}$ ), the ionic current corresponding to $\mathrm{CO}_{2}$ production is almost zero, when the anodes are fed with $\mathrm{H}_{2}$ containing 1000 ppm CO, thus clearly indicating that no WGSR is taking place on the surface of these catalysts. OLMS can be also used to follow extent of $\mathrm{CO}_{2}$ formation during the fuel cell operation, followed by the correlations with the anode overpotential. For doing this, first the fuel cell anode overpotentials are estimated from the fuel cell polarization data and this can be made by calculating the overpotentials introduced by $\mathrm{CO}$ into the hydrogen oxidation reaction (HOR), and assuming that for the HOR the overpotential is negligible (Nepel et al. 2013). In our approach this overpotential (named as $\eta_{\mathrm{CO}}$ ) is calculated by subtraction the values of cell potentials in absence of $\mathrm{CO}\left(\mathrm{E}_{\mathrm{H} 2}\right)$ from that recorded in the presence of $\mathrm{CO}\left(\mathrm{E}_{\mathrm{H} 2 / \mathrm{CO}}\right)$, such as, $\eta_{\mathrm{CO}}=\mathrm{E}_{\mathrm{H} 2}-\mathrm{E}_{\mathrm{H} 2 / \mathrm{CO}}$, for the different current densities during the cell operation, as also stated previously.

Figure 8 shows plots of the fuel cell current densities as a function of the anode overpotentials for several Mo and $\mathrm{W}$ based anode electrocatalysts. In the inset of this Figure, similar plots for $\mathrm{Pt} / \mathrm{C}$ and $\mathrm{PtFe} / \mathrm{C}$ anode catalysts were placed, together 


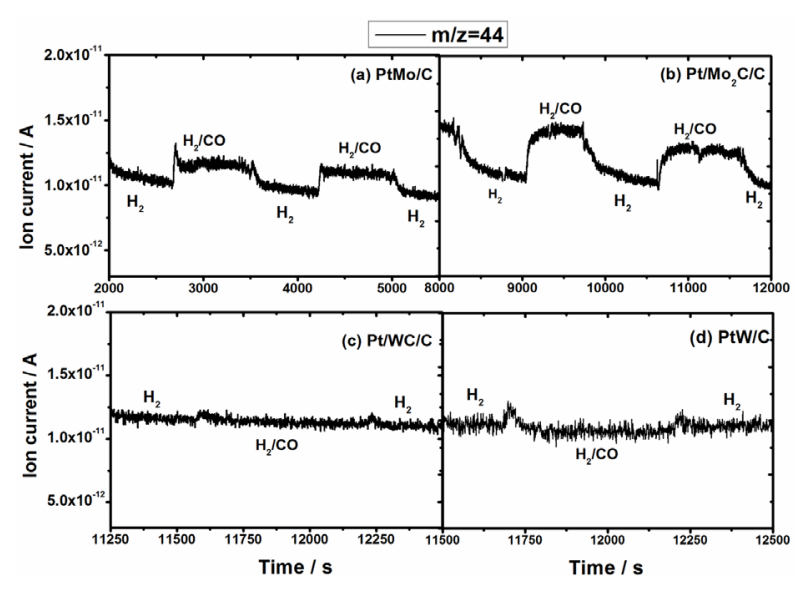

Figure 7 - Online mass spectrometry experiments of $\mathrm{m} / \mathrm{z}=44$ ionic current measurements for the $\mathrm{PtMo} / \mathrm{C}, \mathrm{Pt} / \mathrm{Mo}_{2} \mathrm{C}-\mathrm{C}, \mathrm{Pt} /$ WC-C and $\mathrm{PtW} / \mathrm{C}$ anodes at $85^{\circ} \mathrm{C}$ fed intermittently with pure $\mathrm{H}_{2}$ or $\mathrm{H}_{2} / \mathrm{CO}$ mixtures. $\mathrm{O}_{2}$ is supplied continuously to the $\mathrm{Pt} / \mathrm{C}$ cathodes.

with the corresponding plots of the ionic current in the mass spectrometer for $\mathrm{m} / \mathrm{z}=44 \mathrm{vs}$. the anode overpotential. Two plateau currents for $\mathrm{Pt} / \mathrm{C}$ indicates that the hydrogen oxidation reaction (HOR) currents reach such a as high as $0.2-0.3$ $\mathrm{mAcm}^{-2}$, indicating that even for this catalyst there are vacancies on the $\mathrm{CO}$-adsorbed layer enough to generate such considerably high HOR currents. This occurs even though the CO stripping experiment denotes very high CO coverage, as seen from the complete suppression of the adsorbed hydrogen oxidation currents on $\mathrm{Pt} / \mathrm{C}$ (Fig. 4). In the case of $\mathrm{PtFe} / \mathrm{C}$ the vacancies on the CO-adsorbed layer may be larger, just enough to provide plateau currents of the order of $0.6 \mathrm{~A} \mathrm{~cm}^{-2}$. These results point to the conclusion that the $\mathrm{CO}$ tolerance on $\mathrm{PtFe} / \mathrm{C}$ is enhanced by an electronic effect related to the increase of the $\mathrm{Pt} 5 \mathrm{~d}$ band vacancy introduced by $\mathrm{Fe}$, as confirmed by XANES measurements (Pereira et al. 2006); (ii) after the plateau, the current densities increases with the increase of the anode overpotentials, with the onset of such phenomena intimately related to the onset of $\mathrm{CO}_{2}$ detection by the mass spectrometer, for both catalysts. The current increase occurs earlier for the

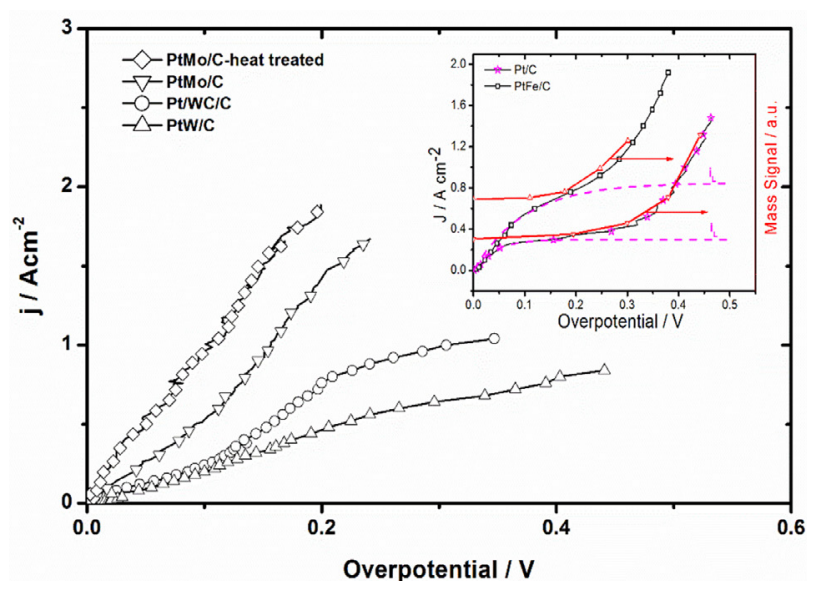

Figure 8 - Current density vs. anode overpotential $\left(\eta_{\mathrm{CO}}=\mathrm{E}_{\mathrm{H} 2}\right.$ $\left.\mathrm{E}_{\mathrm{H} 2 / \mathrm{CO}}\right)$ curves recorded for the single cells at $85^{\circ} \mathrm{C}$ with various freshly prepared anode electrocatalysts, $\mathrm{PtMo} / \mathrm{C}$ heat-treated at $600{ }^{\circ} \mathrm{C}$, as prepared $\mathrm{PtMo} / \mathrm{C}, \mathrm{Pt} / \mathrm{WC} / \mathrm{C}$, and $\mathrm{PtW} / \mathrm{C}$. Inset: similar plots for $\mathrm{Pt} / \mathrm{C}$ and $\mathrm{PtFe} / \mathrm{C}$ fitted to the OLMS results.

$\mathrm{PtFe} / \mathrm{C}$ catalyst, and this is inequivocally related to occurrence of the bifunctional mechanism, for which hydrated oxides electrochemically formed on the iron at lower overpotentials.

Figure 8 evidences the absence of current density plateau in the case of the $\mathrm{PtMo} / \mathrm{C}$ catalysts, while Figure 6 shows that $\mathrm{CO}$ oxidation producing $\mathrm{CO}_{2}$ occurs even at overpotential equal to zero, as expected for the WGS reaction. So, in this case, although the bifunctional mechanism cannot be excluded, it must be concluded that the WGS is a determining factor for the improved $\mathrm{CO}$ tolerance of Mo-based catalysts. In the case of the $\mathrm{W}$-containing catalysts, the presence of plateau current densities with higher magnitudes than $\mathrm{Pt} / \mathrm{C}$ (see insets) denotes the appearance of a benefic electronic effect of $\mathrm{W}$ on Pt leading to an increase $\mathrm{Pt} 5 \mathrm{~d}$ band vacancy that raises the $\mathrm{CO}$ tolerance of these catalysts. A small participation of the bifunctional mechanism cannot be disregarded owing to the tendency of the current to increase along the plateau.

Based on the observations given in Figures 5-8 for the catalyst treated here and other equivalent results for other catalysts, the following reactions 
and processes that characterize the $\mathrm{CO}$ tolerance mechanisms for different electrocatalysts has been proposed:

HOR in absence of $\mathrm{CO}$

$\mathrm{H}_{2}+2 \mathrm{Pt} \rightleftharpoons 2 \mathrm{Pt}-\mathrm{H}$

$\mathrm{Pt}-\mathrm{H} \rightleftharpoons \mathrm{Pt}+\mathrm{H}^{+}+\mathrm{e}^{-}$

Steps related to the presence of $\mathrm{CO}$

- Electronic effect (PtFe, PtRu/C):

$\mathrm{CO}(\mathrm{g})+\mathrm{Pt} \rightleftharpoons \mathrm{Pt}-\mathrm{CO}$

- Langmuir-Hinshelwood (PtMo/C, PtRu/C, $\mathrm{PtFe} / \mathrm{C}$, etc):

$\mathrm{M}+\mathrm{H}_{2} \mathrm{O} \rightarrow \mathrm{M} \mathrm{OH}+\mathrm{H}^{+}+\mathrm{e}^{-}$

$\mathrm{Pt}-\mathrm{CO}+\mathrm{M} \mathrm{OH} \rightarrow \mathrm{Pt}+\mathrm{M}+\mathrm{CO}_{2}+\mathrm{H}^{+}+\mathrm{e}^{-}$

- Partial Oxidation (PtRu/C, PtMo/C (small)):

$\mathrm{CO}_{\text {ads }}+1 / 2 \mathrm{O}_{2} \leftrightarrow \mathrm{CO}_{2}$

- Water gas shift $(\mathrm{PtMo} / \mathrm{C})$ :

$\mathrm{CO}_{\text {ads }}+\mathrm{H}_{2} \mathrm{O} \leftrightarrow \mathrm{CO}_{2}+\mathrm{H}_{2}$

\section{RESULTS}

INVESTIGATIONS OF THE ANODE CATALYST AGING

Though the lifetime requirements of a fuel cell depend upon a particular application, however according to American Department of Energy, $40,000 \mathrm{~h}$ for stationary and from 3000 to $20,000 \mathrm{~h}$ for transportation applications are generally required, which are not usually acquired by pre-commercial PEMFC systems. Several factors affect the stability of the fuel cell system, but the insufficient stability of the catalysts employed in these system is a major contributor. Since, bimetallic alloys of $\mathrm{Pt}$ with some transition metal such as Ru, Mo, W, Fe, Sn,
Pd etc. are usually employed as fuel cell catalysts, the prevailing acidic environment of the fuel cell trigger a partial loss of the second metal $(\mathrm{Ru}, \mathrm{Mo}$, $\mathrm{W}$ etc.) from the catalyst, leading to a reducing catalytic activity with time. Several investigations have been made, where a partial dissolution of these ad-metals have been observed, either during a normal operation of the fuel cell or during stability tests. For example, Pereira et al. (2006) detected the presence of $\mathrm{W}$ species in the cathode side after performing polarization measurements on a PEMFC with PtW/C anode. In a similar way, the presence of $\mathrm{Ru}$ was observed in the $\mathrm{Pt} / \mathrm{C}$ cathode after it had been dissolved from the $\mathrm{PtRu} / \mathrm{C}$ anode during the fuel cell testing (Antolini 2009a). Besides, $\mathrm{Ru}$ and $\mathrm{W}$, Mo also dissolves from the corresponding catalysts, which have been observed through various studies (Hassan et al. 2014a, b, Lebedeva and Janssen 2005).

The cyclic voltammetry technique has been used as accelerated stress test (AST) in order to investigate the stability of the various catalysts, without the need of going to longer time experiments. In these experiments the anode is maintained at $25{ }^{\circ} \mathrm{C}$ and used as working electrode and is constantly fed with Ar, whereas the cathode was used as reference and counter electrode and was constantly fed with $\mathrm{H}_{2}$. The anode potential scanning is first started from 0.1 to $0.8 \mathrm{~V}$ vs RHE at a scan rate of $50 \mathrm{mVs}^{-1}$ and then back to $0.1 \mathrm{~V}$ vs. RHE, repeating this process up to 5000 potential cycles. Figure 9 shows polarization curves for various catalysts supplied first with pure $\mathrm{H}_{2}$ and then $\mathrm{H}_{2}$ containing $\mathrm{CO}$ after these several voltage cycles. As can be seen for PtMo/C (Fig. 9a), the cell voltage decreases continuously along the voltage cyclic process in both cases $\left(\mathrm{H}_{2}\right.$ and $\left.\mathrm{H}_{2} / \mathrm{CO}\right)$. This shows that some degradation process occur in this catalyst, which leads to the decrease in activity, and evidence the poor stability of this catalyst. For Pt/ $\mathrm{Mo}_{2} \mathrm{C} / \mathrm{C}$ (Fig. 9b) the cell voltage initially decreases up to 3000 cycles, but then remains constant up to 
5000 cycles. This shows that the carbide phase in this catalyst impart some stability for this catalyst in comparison to carbon support of the $\mathrm{PtMo} / \mathrm{C}$ catalyst. Not only the carbide phase, but also the heat treatment of $\mathrm{PtMo} / \mathrm{C}$ improves the stability of the resultant catalyst, as seen previously by fuel cell current voltage curves in the presence of both $\mathrm{H}_{2}$ and $\mathrm{H}_{2}$ containing $\mathrm{CO}$ (Hassan et al. 2014a). The increase in the stability of $\mathrm{PtMo} / \mathrm{C}$ catalyst with heat treatment may be either due to the increase in the particle size of metal particles, as larger particles are more stable than fine particles, or due to the increase in the extent of metal support interaction. $\mathrm{Pt} / \mathrm{WC} / \mathrm{C}$ catalyst shows an almost constant activity along the cycling in the presence of pure $\mathrm{H}_{2}$ and a slight decline in the presence of $\mathrm{H}_{2} / \mathrm{CO}$ mixture (Fig. 9c). This shows that, WC imparts more stability to the catalyst as compared to $\mathrm{Mo}_{2} \mathrm{C}$, which in turn improve the stability compared to carbon black. The lower stability of carbon-supported catalyst was also confirmed by the $\mathrm{PtW} / \mathrm{C}$ catalyst which similarly to $\mathrm{PtMo} / \mathrm{C}$, shows a regular decline in the hydrogen oxidation activity along the voltage cycling procedure with both $\mathrm{H}_{2}$ and $\mathrm{H}_{2} / \mathrm{CO}$. In an earlier reported work (Hassan et al. 2015), a steady cell performance is reported up to 3000 cycles, either in the presence of pure $\mathrm{H}_{2}$ or $\mathrm{H}_{2} / \mathrm{CO}$ for the $\mathrm{Pt} / \mathrm{C}$ catalyst. In this case, the greater stability may be due the absence of a second metal used for improving the $\mathrm{CO}$ tolerance, which usually undergo dissolution affecting the overall cell performance.

Figure 10 shows cyclic voltammetry results for $\mathrm{PtMo} / \mathrm{C}, \mathrm{PtMo} / \mathrm{C}$-heat treated, $\mathrm{Pt} / \mathrm{Mo}_{2} \mathrm{C} / \mathrm{C}, \mathrm{Pt} /$ $\mathrm{WC} / \mathrm{C}, \mathrm{PtW} / \mathrm{C}$ and $\mathrm{PtMoRuFe} / \mathrm{C}$ single cell anode electrocatalysts, obtained prior the anode cycling and after 1000, 3000 and 5000 cycles. In addition to the well-known Pt-H adsorption/desorption peaks, an oxidation peak can be observed at ca. $0.45 \mathrm{~V}$ vs. RHE in the forward scan and a reduction peak can be observed at $0.42 \mathrm{~V}$ vs. RHE in the reverse scan, for $\mathrm{PtMo} / \mathrm{C}$, PtMo/C-heat treated and $\mathrm{Pt} / \mathrm{Mo}_{2} \mathrm{C}-\mathrm{C}$

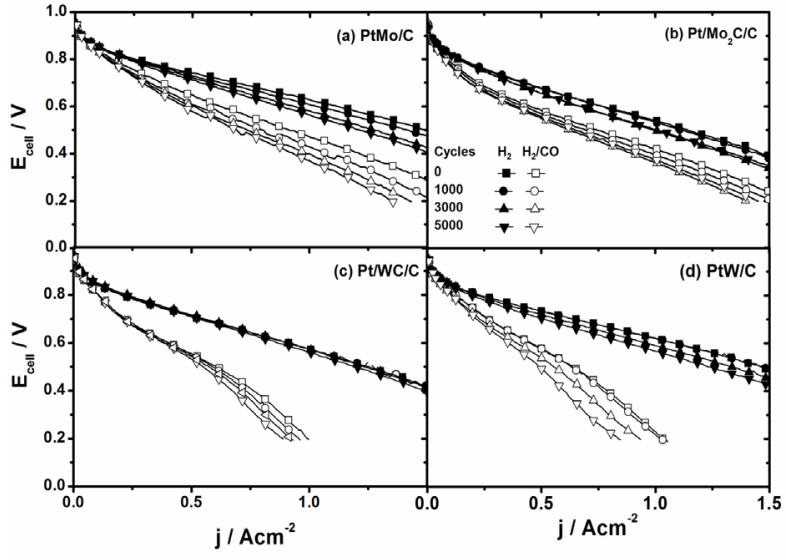

Figure 9 - Single cell polarization curves measured at $85{ }^{\circ} \mathrm{C}$ for different catalysts after various voltage cycles during the AST: (a) The $\mathrm{PtMo} / \mathrm{C}, \mathrm{Pt} / \mathrm{Mo}_{2} \mathrm{C}-\mathrm{C}, \mathrm{PtW} / \mathrm{C}$ and $\mathrm{Pt} / \mathrm{C}$ anodes were supplied with pure $\mathrm{H}_{2}$ and $\mathrm{H}_{2} / \mathrm{CO}$ mixture and the $\mathrm{Pt} / \mathrm{C}$ cathodes were supplied with $\mathrm{O}_{2}$.

catalysts (Figs. 10a to 10c). This redox couple is due to the change in the oxidation states of $\mathrm{Mo}$ from +4 to +6 and vice versa during the oxidation/reduction processes, as reported in the literature (11). For Pt/ $\mathrm{WC} / \mathrm{C}$ and PtW/C catalysts (Figs. 10d and 10e), the peaks present in the potential range of $0.3-0.4 \mathrm{~V}$ are due to the oxidation/reduction of $\mathrm{W}^{+4}$ into $\mathrm{W}^{+5}$ and vice versa, or due to hydrogen intercalation into $\mathrm{WO}_{\mathrm{x}}$, forming bronze tungstate species (Chhina et al. 2007). On the other hand, broad peaks in the potential range of 0.3 to $0.6 \mathrm{~V}$ can be seen in the cyclic voltammogram of the PtMoRuFe/C catalyst (Fig. 10f). Since Ru does not exhibit characteristic peaks in the cyclic voltammograms, but the increase of the currents in the hydrogen region provides a clear evidence of the presence of $\mathrm{Ru}$, with almost no changes with the electrode cycling.

For all the Mo based catalysts, a decline in the intensity of the peak currents corresponding to the oxidation/reduction of Mo species is observed during the cycling process, suggesting that partial dissolution of such species occurs due to the oxidizing condition of the cell (Cindrellaa et al. 2009). However, for PtMo/C-heat treated (Fig. 10b) and $\mathrm{Pt} / \mathrm{Mo}_{2} \mathrm{C} / \mathrm{C}$ (Fig. 10c) the current densities remain constant after they are cycled up 


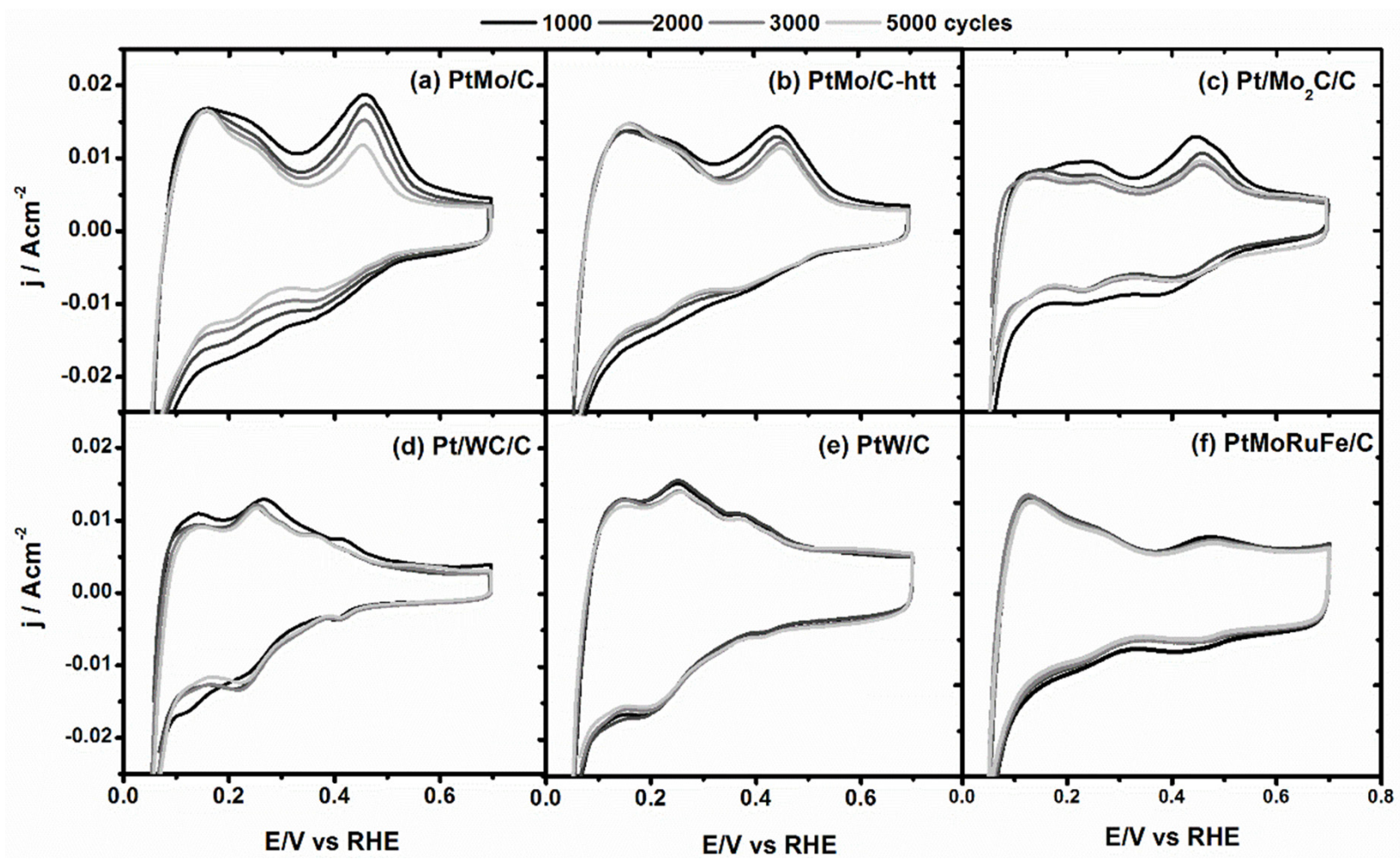

Figure 10 - Cyclic voltammograms obtained at $25^{\circ} \mathrm{C}$ for various anodes composed of different catalysts; $\mathrm{PtMo} / \mathrm{C}(\mathbf{a}), \mathrm{PtMo} / \mathrm{C}$-heat treated (b), Pt/Mo $2 \mathrm{C} / \mathrm{C}(\mathbf{c}), \mathrm{Pt} / \mathrm{WC} / \mathrm{C}(\mathbf{d}), \mathrm{PtW} / \mathrm{C}$ (e) and $\mathrm{PtMoRuFe} / \mathrm{C}$ (f) recorded after 1000, 3000 and 5000 voltage AST cycles. For these measurements, the anodes were supplied with $\mathrm{Ar}$ and the cathodes with pure $\mathrm{H}_{2}$.

to 1000 cycles, indicating that after the releasing of some Mo ionic species, further dissolution is very small. Alternatively, the PtMo/C catalyst (Fig. 10a) undergoes a regular decrease in the current density, which remains up to the end of the voltage cycling. This indicates that not only the heat treatment but also the $\mathrm{Mo}_{2} \mathrm{C}$ phase impart stability to the corresponding catalysts, which make them more resistant towards dissolution of Mo species. PtW/C presents constant $\mathrm{CV}$ current densities during all voltage cycling process, evidencing only small dissolution of W species from this catalyst. Similar observation is made for $\mathrm{PtMoRuFe} / \mathrm{C}$ catalyst.

The consequences of dissolution of $\mathrm{W}$ and Mo ions from the anode catalysts and their transport through the electrolyte membrane towards the $\mathrm{Pt} / \mathrm{C}$ cathodes has been investigated by recording the cyclic voltammograms of the $\mathrm{Pt} / \mathrm{C}$ cathodes after 5000 voltage cycling of the anodes. These results are shown in Figure 11. Different peaks at different potentials are noticed in these voltammograms, except for the cathode of the cell with the $\mathrm{Pt} / \mathrm{C}$ anode. Since the extra peaks are located at the same potentials as those of the corresponding anode, these results confirm the migration of both Mo and $\mathrm{W}$ species from the anodes to the cathode, after crossing the membrane. A difference in the current densities of Mo-related peaks has been observed in the cyclic voltammograms of $\mathrm{Pt} / \mathrm{C}$ cathodes, whose anode counterpart is made of $\mathrm{PtMo} / \mathrm{C}$ and $\mathrm{Pt} / \mathrm{Mo}_{2} \mathrm{C} / \mathrm{C}$ catalysts (Hassan et al. 2014b). This clearly evidences that a larger amount of Mo species are dissolved from $\mathrm{PtMo} / \mathrm{C}$, as compared to $\mathrm{Pt} / \mathrm{Mo}_{2} \mathrm{C} / \mathrm{C}$. The intensities of the extra-peaks in the case of the $\mathrm{Pt} / \mathrm{C}$ cathodes for the cells with $\mathrm{Pt} /$ $\mathrm{WC} / \mathrm{C}$ and $\mathrm{PtW} / \mathrm{C}$ anodes are negligibly small, in accordance with the small amount of $\mathrm{W}$ species dissolved from these anode catalysts. Results in 


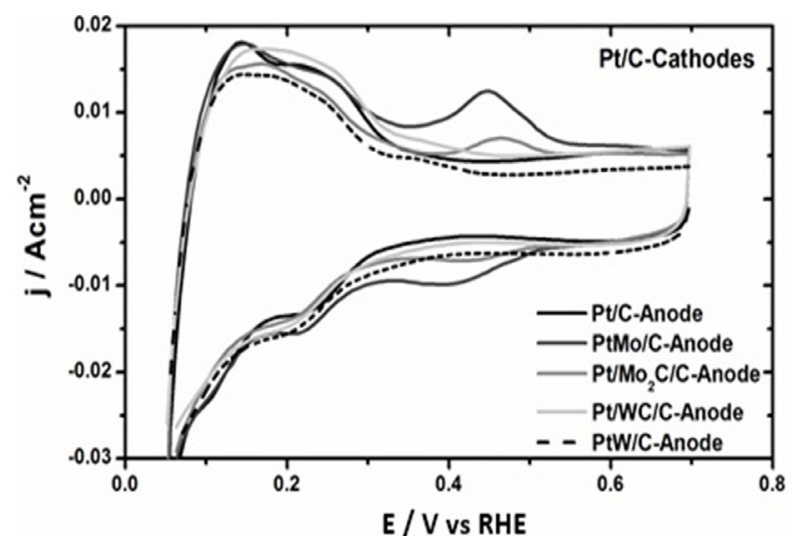

Figure 11 - Cyclic voltammograms obtained at $25{ }^{\circ} \mathrm{C}$ for the various $\mathrm{Pt} / \mathrm{C}$ cathodes recorded after 5000 voltage AST cycles of the corresponding anodes in the potential window of 0.1 to $0.8 \mathrm{~V}$ vs RHE. For these measurements, the cathodes were supplied with $\mathrm{Ar}$ and the anodes with pure $\mathrm{H}_{2}$.

Figures 10 and 11 clearly evidences that a greater amount of Mo-species is dissolved from $\mathrm{PtMo} / \mathrm{C}$, as compared to $\mathrm{Pt} / \mathrm{Mo}_{2} \mathrm{C} / \mathrm{C}$, followed by $\mathrm{PtMo} / \mathrm{C}$-heat treated. This is in close agreement with the current voltage curves obtained for single cell anodes supplied with $\mathrm{H}_{2}$ without and with $\mathrm{CO}$, where the decline in the cell potentials after the various voltage cycles followed the sequence: $\mathrm{PtMo} / \mathrm{C}$ heat treated $<\mathrm{Pt} / \mathrm{Mo}_{2} \mathrm{C} / \mathrm{C}<<\mathrm{PtMo} / \mathrm{C}$. Thus, not only an improved $\mathrm{CO}$ tolerance was observed for $\mathrm{PtMo} / \mathrm{C}$-heat treated and $\mathrm{Pt} / \mathrm{Mo}_{2} \mathrm{C} / \mathrm{C}$ catalysts, but also a greater stability was noticed compared to conventional carbon supported PtMo catalyst. For $\mathrm{Pt} / \mathrm{WC} / \mathrm{C}, \mathrm{PtW} / \mathrm{C}$ and $\mathrm{Pt} / \mathrm{C}$ catalysts, almost no decline in the $\mathrm{CV}$ current density was observed after the cycling process, which is consistent with the polarization measurement, where almost constant cell voltages were observed with the cycling for the single cell anodes supplied with pure $\mathrm{H}_{2}$. However, the changes occurring in the $\mathrm{W}$ species of the anode during cycling process trigger a decline in the cell voltage supplied with $\mathrm{H}_{2} / \mathrm{CO}$ mixture, as seen from the results in Figure 8. Results in Figures 10 and 11 suggest that Mo-species dissolves more readily as compared to the $\mathrm{W}$-species from the anode catalyst, although the latter is not as efficient as the first one for the $\mathrm{CO}$ tolerance. Activity and stability are the two fundamental properties of a good catalyst, and these are described by the active phase as well as the support material. Here, it is seen that the PtMo/ $\mathrm{C}$-heat treated gave the maximum CO tolerance and highest stability, so that it is considered as the best PEMFC anodic catalyst, among the Mo based materials. Similarly, the results showed that $\mathrm{Pt} /$ $\mathrm{WC} / \mathrm{C}$ is a more efficient catalyst than $\mathrm{PtW} / \mathrm{C}$ in term of CO tolerance and stability, but in the overall it is inferior in the performance to the $\mathrm{PtMo} / \mathrm{C}$-heat treated material.

Scanning electron microscopy and wavelength dispersive X-ray analyses of new and used samples of the MEAs were performed, for the purpose of following the dissolution of Mo species from the $\mathrm{PtMo} / \mathrm{C}$ electrocatalyst and its diffusion and passage to the electrolyte membrane and cathode side. SEM analysis has been performed using a field emission scanning electron microscope (FESEM, SIGMA-Carl Zeiss), while the electron probe microanalysis (EPMA) was performed in a electron probe microanalyzer (JEOL JXA 8230), using a wavelength dispersive spectrometer (WDS) and a PETJ analyzer crystal. Experiments were conducted in the Laboratorio de Microscopía Electrónica y Análisis por RayosX, from the Facultad de Matemática, Astronomía y Física (FAMAF), Universidad Nacional de Córdoba, Argentina. For this purpose, samples of MEAs were cut crosswise, fixed in sample holders (Al) and covered with a carbon layer, for increasing the surface thermal and electrical conductivities. To study the transport of the Mo species, SEM and X-ray analysis of both the new and cycled MEAs were carried out. Figures $12 \mathrm{a}$ and $\mathrm{b}$ show SEM images of cross sections of the MEAs (having as-prepared $\mathrm{PtMo} / \mathrm{C}$ and $\mathrm{Pt} / \mathrm{C}$ in the anode and cathode sides, respectively), recorded before and after the voltage cycling testing. The carbon cloth fibers, the catalyst layers (both anode and cathode), and the membrane can be easily seen in the new 

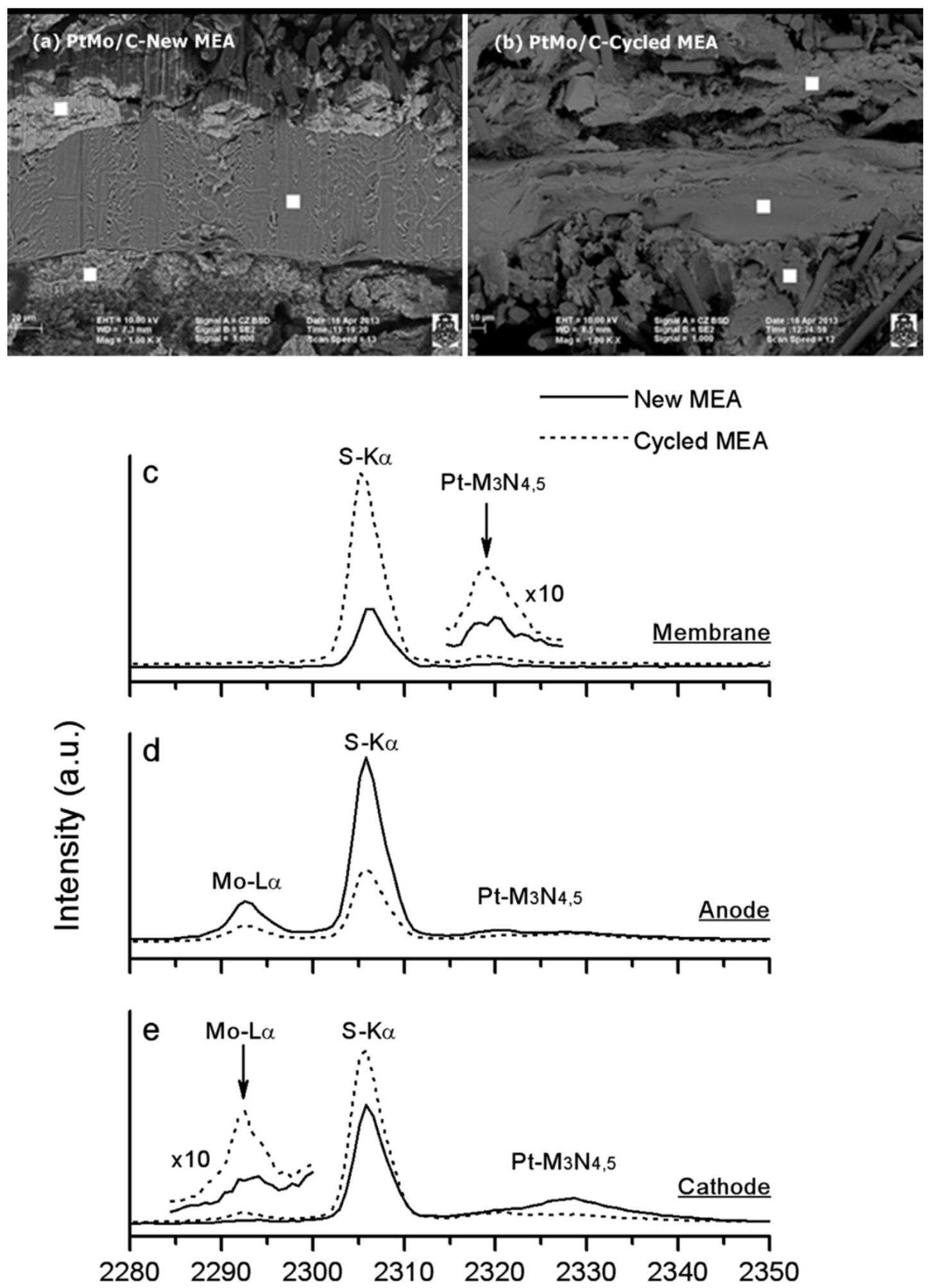

Figure 12 - Scanning electron micrographs of cross sections of the new (a) and cycled (b) MEAs, recorded with backscattered electrons. WDS spectra of the membranes (c), anodes (d) and cathodes (e) of both MEAs, acquired with a $20 \mathrm{keV}$ incident electron beam, in the energy range between 2.28 and $2.35 \mathrm{keV}$, corresponding to the areas indicated with the white spots in the micrographs (a) and (b). (Reprinted with permission from Hassan et al. 2014a). 
and cycled MEAs. Some signs of worsening, such as appearance of rupture in the gas diffusion layer, detachment of nanoparticle from the diffusion layer, coarsening of membrane etc. can be observed in the cycled MEA, which are mainly caused by the voltage cycling process.

WDX spectra of the three main components (membrane, anode and cathode) of both new and cycled MEAs, recorded in the energy range between 2.28 and $2.35 \mathrm{keV}$ with a $20 \mathrm{keV}$ incident electron beam are shown in Figures 11c, d and e. Several different regions were used for recording these spectra (marked with white squares in Figs. 12a and b). A pairs of peaks can be observed in these spectra with the S-K $\alpha$ seen in almost all the spectra, and is assigned to the $\mathrm{S}$ content of the electrolyte membrane. The Mo-L $\alpha$ and Pt-M3N4.5 peaks apparent in the spectra of the anodes are related to the presence of Mo and $\mathrm{Pt}$ of the $\mathrm{PtMo} / \mathrm{C}$ catalyst, respectively. On the other hand, the Pt-M3N4.5 peak is recorded in the spectra of the cathode together with the Mo-L $\alpha$ peak particularly in the cycled MEA, confirming that the $\mathrm{Pt} / \mathrm{C}$ cathode is contaminated with Mo. Finally, a Pt-M3N4.5 peak can also be observed in the membranes, but in this case, the contamination of the membrane is probably produced during the sample preparation by making a transversal cut in the MEAs. These finding are in close agreement with the data from cyclic voltammetry obtained for the $\mathrm{Pt} / \mathrm{C}$ cathodes after 5000 voltage cycles (see Fig. 11). Thus, these measurements clearly confirm that during the course of ageing process, Mo is partly dissolved from the anode catalyst, crosses the electrolyte membrane, and move towards the Pt cathode, as was already mentioned. Some of the Mo species surely entrap in the membrane affecting the conductivity of the electrolyte, as observed previously through impedance spectroscopy (Hassan et al. 2014c). The authors reported a slight increase in the resistance in the high frequency region of the impedance spectra recorded after 5000 cycles of the single fuel cell cathode, and this has been attributed to the contamination of the membrane by migrating ionic species (Mo, Fe and $\mathrm{Ru}$ ) from the anode towards the cathode.

\section{CONCLUSIONS}

The activity of various electrocatalyts was discussed for the $\mathrm{CO}$ tolerance in the anode of proton exchange membrane fuel cell. On the bases of polarization measurements, it was concluded that the $\mathrm{PtMo} / \mathrm{C}$ heat treated, $\mathrm{Pt} / \mathrm{MoC} / \mathrm{C}$ and $\mathrm{PtMoRuFe} / \mathrm{C}$ catalysts showed more stable hydrogen oxidation activity in the presence of hydrogen containing $100 \mathrm{ppm}$ of $\mathrm{CO}$ as compared to that of the as prepared $\mathrm{PtMo} / \mathrm{C}$ catalyst. The stability study revealed that all the Mo based electrocatalysts suffer from partial dissolution ofMo, but this can be reduced effectively by applying heat treatment to the PtMo catalyst or by using molybdenum carbide as catalyst support. Similarly, the addition of a third or fourth element to the $\mathrm{PtMo} / \mathrm{C}$, also improves the stability of the resultant catalyst to a greater extent.

\section{ACKNOWLEDGMENTS}

The authors would like to thank the The World Academy of Science (TWAS), Italy, the Conselho Nacional de Desenvolvimento Científico e Tecnológico (CNPq) and Fundação de Amparo à Pesquisa do Estado de São Paulo (FAPESP - Proc. 2013/16930-7), Brazil for financial supports.

\section{REFERENCES}

ANTOLINI E. 2009. Carbon supports for low-temperature fuel cell catalysts. Appl Catal B Environ 88(1-2): 1-24.

ANTOLINI E. 2016. Iron-containing platinum-based catalysts as cathode and anode materials for low-temperature acidic fuel cells: a review. RCS Adv 6: 3307-3325.

ARICÒ AS, ANTONUCCI V, PINO L AND ANTONUCCI PL. 1990. The role of Pt-loading, thermal treatment and exposure to air on the acid-base behavior of a Pt/carbon black catalyst Giordano N. Carbon 28: 599-609. 
AUER E, FREUND A, PIETSCH J AND TACKE T. 1998. Carbons as supports for industrial precious metal catalysts. Appl Catal A Gen 173: 259-271.

BASCHUK JJ AND LI X. 2003. Modelling CO poisoning and $\mathrm{O}_{2}$ bleeding in a PEM fuel cell anode. Int $\mathrm{J}$ Energ Res 27(12): 1095-1116.

CAO Y, YANG Y, SHAN Y AND HUANG Z. 2016. One-Pot and Facile Fabrication of Hierarchical Branched $\mathrm{Pt}-\mathrm{Cu}$ Nanoparticles as Excellent Electrocatalysts for Direct Methanol Fuel Cells. ACS Appl Mater Interfaces. 8: 59986003.

CHEN JG. 1996. Carbide and Nitride Overlayers on Early Transition Metal Surfaces: Preparation, Characterization, and Reactivities. Chem Rev 96: 1477-1498.

CHEN WX, LEE JY AND LIU Z. 2004. Preparation of Pt and PtRu nanoparticles supported on carbon nanotubes by microwave-assisted heating polyol process. Mater Lett 58: 3166-3169.

CHHINA H, CAMPBELL S AND KESLER O. 2007. High surface area synthesis, electrochemical activity, and stability of tungsten carbide supported Pt during oxygen reduction in proton exchange membrane fuel cells. J Power Sources 164: 431-440.

CHUNG C, CHEN C, WENG D, YAN Y and LIN HJ. 2007. Investigation of Cell Operation Conditions for $\mathrm{CO}$ Tolerance Improvement of PEMFC. Chin Soc Mech Eng 32: 563-569.

CINDRELLA L, KANNAN AM, LIN JF, SAMINATHAN K, HO Y, LIN CW and WERT J. 2009. Gas diffusion layer for proton exchange membrane fuel cells-A review. J Power Sources 194: 146-160.

DOU M, HOU M, ZHANG H, LI G, LU W, WEI Z, SHAO Z AND YI B. 2012. A Highly Stable Anode, CarbonFree, Catalyst Support Based on Tungsten Trioxide Nanoclusters for Proton-Exchange Membrane Fuel Cells. ChemSusChem 5: 945-951.

GARCIA AC, PAGANIN VA AND TICIANELLI EA. 2008. $\mathrm{CO}$ tolerance of $\mathrm{PdPt} / \mathrm{C}$ and $\mathrm{PdPtRu} / \mathrm{C}$ anodes for PEMFC. Electrochim Acta 53: 4309-4315.

GRGUR BN, MARKOVIC NM AND ROSS PN JR. 1998. Electrooxidation of $\mathrm{H} 2, \mathrm{CO}$, and $\mathrm{H}_{2} / \mathrm{CO}$ Mixtures on a Well-Characterized Pt70Mo30 Bulk Alloy Electrode. J Phys Chem B 102: 2494-2501.

GRGUR BN, MARKOVIC NM AND ROSS PN JR. 1999. The Electro-oxidation of $\mathrm{H} 2$ and $\mathrm{H} 2 / \mathrm{CO}$ Mixtures on CarbonSupported Ptx Moy Alloy Catalysts. J Electrochem Soc 146: 1613-1619.

GRGUR BN, ZHUANG G, MARKOVIC NM AND ROSS PN JR. 1997. Electrooxidation of H2/CO Mixtures on a WellCharacterized Pt 75 Mo 25 Alloy Surface. J Phys Chem B 101: 3910-3913.

GUILLÉN-VILLAFUERTE O, GUIL-LÓPEZ R, NIETO E, GARCÍA G, RODRÍGUEZ JL, PASTOR E AND FIERRO
JLG. 2002. Electrocatalytic performance of different Mophases obtained during the preparation of innovative PtMoC catalysts for DMFC anode. Int J Hydrogen Energy 37(8): 7171-7179.

HAM DJ AND LEE JS. 2009. Transition Metal Carbides and Nitrides as Electrode Materials for Low Temperature Fuel Cells. Energies 2: 873-899.

HASSAN A, CARRERAS A, TRINCAVELLI J AND TICIANELLI EA. 2014a. Effect of heat treatment on the activity and stability of carbon supported PtMo alloy electrocatalysts for hydrogen oxidation in proton exchange membrane fuel cells J Power Sources 247: 712-720.

HASSANA, PAGANIN VA, CARRERAS AAND TICIANELLI EA. 2014b. Molybdenum carbide-based electrocatalysts for $\mathrm{CO}$ tolerance in proton exchange membrane fuel cell anodes. Electrochim Acta 142: 307-316.

HASSAN A, PAGANIN VA, CARRERAS A AND TICIANELLI EA. 2014c. Effect of Addition of Ru and/ or Fe in the Stability of PtMo/C Electrocatalysts in Proton Exchange Membrane Fuel Cells. Electrocatal 6: 512-520.

HASSAN A, PAGANIN VA AND TICIANELLI EA. 2015. Pt modified tungsten carbide as anode electrocatalyst for hydrogen oxidation in proton exchange membrane fuel cell: CO tolerance and stability. Appl Catal B Environ 165: 611-619.

HOFFMANN J, MEUSEL I, HARTMANN J, LIBUDA J AND FREUND HJ. 2001. Reaction Kinetics on Heterogeneous Model Catalysts. J Catal 204: 378-392.

HYEON T, FANG M AND SUSLICK KS. 1996. Nanostructured Molybdenum Carbide: Sonochemical Synthesis and Catalytic Properties. J Am Chem Soc 7863: 5492-5493.

JOO JB, KIM JS, KIM P AND YI J. 2008. Simple preparation of tungsten carbide supported on carbon for use as acatalyst suuport in a methanol electrooxidation. Mater Lett 62: 3497-3499.

KIM P, JOO JB, KIM W, KIM J. SONG IK AND YI J. 2006. $\mathrm{NaBH} 4$-assisted ethylene glycol reduction for preparation of carbon-supported Pt catalyst for methanol electrooxidation. J Power Sources 160: 987-990.

KONINGSBERGER DC, GRAAF J DE, MOJET BL, RAMAKER DE AND MILLER JT. 2000. The metalsupport interaction in $\mathrm{Pt} / \mathrm{Y}$ zeolite: evidence for a shift in energy of metal d-valence orbitals by $\mathrm{Pt}-\mathrm{H}$ shape resonance and atomic XAFS spectroscopy. Appl Catal A Gen 191: 205-220.

KWON K, JUNG Y, KU H, LEE KH, KIM S, SOHN J AND PAK C. 2016. CO-tolerant Pt-BeO as novel electrocatalyst in proton exchange membrane fuel cells. Catalysts 6: 5 .

LEBEDEVA NP AND JANSSEN GJM. 2005. On the preparation and stability of bimetallic $\mathrm{PtMo} / \mathrm{C}$ anodes for proton-exchange membrane fuel cells Electrochim Acta 51: $29-40$. 
LEE D, HWANG S AND LEE I. 2005. A study on composite PtRu(1:1)-PtSn(3:1) anode catalyst for PEMFC J Power Sources 145: 147-153.

LEMIRE C AND MEYER R. 2004. Do quantum size effects control CO adsorption on gold nanoparticles. Angew Chemie Int Ed 43: 118-121.

LENG YJ, WANG X AND HSING IM. 2002. Assessment of CO-tolerance for different Pt-alloy anode catalysts in a polymer electrolyte fuel cell using ac impedance spectroscopy J Electroanal Chem 532: 145-152.

LIANG ZX, ZHAO TS AND XU JB. 2008. Stabilization of the platinum-ruthenium electrocatalyst against the dissolution of ruthenium with the incorporation of gold. J Power Sources 185: 166.

LI Q, HE R, GAO JA, JENSEN JO AND BJERRUM NJ. 2003. The CO poisoning effect in PEMFCs operational at temperatures up to $200 \mathrm{C}$. J Electrochem Soc 150(12): A1599-605.

LIU LQ, ZHOU F, KODIYATH R, UEDA S, ABE H, WANG DF, DENG YQ AND YE JH. 2016. CO tolerance of Pt/ $\mathrm{FeO}_{x}$ catalyst in both thermal catalytic $\mathrm{H}_{2}$ oxidation and electrochemical $\mathrm{CO}$ oxidation: effect of $\mathrm{Pt}$ deficit of electron state. PhysChemChemPhys 18: 29607-29615.

LI X, LIU J, HUANG Q, VOGEL W, AKINS DL AND YANG H. 2010. Effect of heat treatment on stability of gold particle modified carbon supported $\mathrm{Pt}-\mathrm{Ru}$ anode catalysts for a direct methanol fuel cell. Electrochim Acta 56: 278.

LOPES PP, FREITAS KS AND EDSON EA. 2010. CO Tolerance of PEMFC Anodes: Mechanisms and Electrode Designs. Electrocatal 1: 200-212.

LU G, COOPER JS AND MCGINN PJ. 2006. SECM characterization of PT-Ru-WC and Pt-Ru-Co ternary thin film combinational libraries as anode electrocatalysts for PEMFC. J Power Sources 161: 106-114.

MANASILP A AND GULARI E. 2002. Selective CO oxidation over Pt/alumina catalysts for fuel cell applications. Appl Catal B Environ 37: 17-25.

MILLER JT, MOJET BL, RAMAKER DE AND KONINGSBERGER DC. 2000. A new model for the metal-support interaction Evidence for a shift in the energy of the valence orbitals Catal Today 62: 101-114.

MUKERJEE S, LEE SJ, TICIANELLI EA, MCBREEN J, GRGUR BN, MARKOVIC NM, ROSS PN, GIALLOMBARDO JR AND DE CASTRO ES. 1999. Investigation of enhanced $\mathrm{CO}$ tolerance in proton exchange membrane fuel cells by carbon supported PtMo alloy catalyst. Electrochem Solid-State Lett 2: 12-15.

MUKERJEE S, URIAN RC, LEE SJ, TICIANELLI EA AND MCBREEN J. 2004. Electrocatalysis of CO Tolerance by Carbon-Supported PtMo Electrocatalysts in PEMFCs. J Electrochem Soc 151(7): A1094-A1103.

NEPEL TCM, LOPES PP, PAGANIN VA AND TICIANELLI EA. 2013. CO tolerance of protonexchange membrane fuel cells with $\mathrm{Pt} / \mathrm{C}$ and $\mathrm{PtMo} / \mathrm{C}$ anodes operating athigh temperatures: A mass spectrometry investigation. Electrochim Acta 88: 217.

ORDÓÑEZ LC, ROQUERO P, SEBASTIAN PJ AND RAMÍREZ J. 2005. Carbon-supported platinummolybdenum electro-catalysts for methanol oxidation. Catal Today 107-108: 46-52

PANG M, LI C, DING L, ZHANG J, SU D, LI W AND LIANG C. 2010. Microwave-assisted prepa- ration of Mo2C/CNTs nanocomposites as efficient electrocatalyst supports for oxygen reduction reaction Ind Eng Chem Res 49: 4169-4174.

PATT J, JU D, PHILLIPS C AND THOMPSON L. 2000. Molybdenum carbide catalysts for water-gas shift. Catal Lett 65: 193-195.

PEIGHAMBARDOUST SJ, ROWSHANZAMIR S AND AMJADI M. 2010. Review of the proton exchange membranes for fuel cell applications Int J Hydrogen Energy 17(35): 9349-9384.

PEREIRA LGS, DOS SANTOS FR, PEREIRA ME, PAGANIN VA AND TICIANELLI EA. 2006. CO tolerance effects of tungsten-based PEMFC anodes. Electrochim Acta 51: 4061-4066.

PEREIRA LGS, PAGANIN VAAND TICIANELLI EA. 2009. Investigation of the $\mathrm{CO}$ tolerance mechanism at several Ptbased bimetallic anode electrocatalysts in a PEM fuel cell. Electrochim Acta 54: 1992-1998.

RALPH TR AND HOGARTH MP. 2002. Catalysis for Low Temperature Fuel Cells. Platinum Met Rev 4(46): 146-164.

RUSSELL AE, BALL SC, MANIGUET SAND THOMPSETT DU. 2007. Unravelling the complexities of $\mathrm{CO} 2$ tolerance at PtRu/C and PtMo/C. J Power Sources 171: 72-78.

SANTIAGO EI, CAMARA GAAND TICIANELLI EA. 2003. $\mathrm{CO}$ tolerance on $\mathrm{PtMo} / \mathrm{C}$ electrocatalysts prepared by the formic acid method. Electrochim Acta 48: 3527-3534.

SANTIAGO EI, BATISTA MS, ASSAF EM AND TICIANELLI EA. 2004. Mechanism of CO Tolerance on Molybdenum-Based Electrocatalysts for PEMFC. J Electrochem Soc 151: A944.

SCHAIDLE JA, LAUSCHE AC AND THOMPSON LT. 2010. On the preparation of molybdenum carbide-supported metal catalysts. J Catal 272: 235-245.

SCHAIDLE JA, SCHWEITZER NM, AJENIFUJAH OT AND THOMPSON LT. 2012. Effects of sulfur on Mo2C and $\mathrm{Pt} / \mathrm{Mo} 2 \mathrm{C}$ catalysts: Water gas shift reaction. J Catal 289: 210-217.

SUSLICK KS, HYEON T, FANG M AND AVE SM. 1996. Nanostructured Materials Generated by High-Intensity Ultrasound : Sonochemical Synthesis and Catalytic Studies. Chem Mater 4756: 2172-2179.

TAUSTER SJ AND FUNG SC. 1978. Strong metal-support interactions: occurrence among the binary oxides of groups IIA-VB. J Catal 55: 29-35. 
TICIANELLI EA, CAMARA GA AND SANTOS LGRA. 2005. Electrocatalysis of the hydrogen oxidation and oxygen reduction reactions. Quim Nova 32: 664-669.

TRIANTAFILLOU ND, MILLER JT AND GATES BC. 1995. Iridium Clusters in KLTL Zeolite: Structure and Catalytic Selectivity for n-Hexane Aromaitzation. J Catal 155: 131140.

URIAN RC, GULLÁ AF AND MUKERJEE S, 2003. Electrocatalysis of reformate tolerance in proton exchange membranes fuel-cells: Part I. J Electroanal Chem 307: 554-555.

WANG G, HOVE MA, ROSS PN AND BASKES MI. 2005. Surface structures of cubo-octahedral Pt-Mo catalyst nanoparticles from Monte Carlo simulations. J Phys Chem B 109: 11683-92.

WATWE RM, SPIEWAK BE, CORTRIGHT RD AND DUMESIC JA. 1998. Density-Functional Theory (Dft) And Microcalorimetric Investigations Of Co Adsorption On Pt Clusters. Catal Letters 51: 139-147.

WEE JH AND LEE KY. 2006. Overview of the development of CO-tolerant anode electrocatalysts for proton-exchange membrane fuel cells. J Power Sources 157: 128-135.
WEIGERT EC, SMITH NA, WILLIS BG, AMORELLI A AND CHEN JG. 2010. PVD synthesis and characterization of Pt-modified molybdenum carbides as potential electrocatalysts. Electrochem Solid-State Lett 8(7): A337-A340.

WOJCIESZAK R, ZIELIŃSKI M, MONTEVERDI S AND BETTAHAR MM. 2006. Study of nickel nanoparticles supported on activated carbon prepared by aqueous hydrazine reduction. J Colloid Interface Sci 299: 238-248.

ZHANG ZC, TIAN XC, ZHANG BW, HUANG L, ZHU FC, QU XM, LIU L, LIU S, JIANG XY AND SU SG. 2017. Engineering phase and surface composition of $\mathrm{Pt}_{3} \mathrm{Co}$ nanocatalysts: A strategy for enhancing the $\mathrm{CO}$ tolerance. Nano Energy 34: 224-232.

ZHANG Q, YANG Z, DING B, LAN X AND GUO Y. 2010. Preparation of copper nanoparticles by chemical reduction method using potassium borohydride. Trans Nonferrous Met Soc China 20: s240-s244.

ZHANG J, WANG X, WU C, WANG H, YI B AND ZHANG H. 2004. Preparation and characterization of $\mathrm{Pt} / \mathrm{C}$ catalysts for PEMFC cathode: effect of different reduction methods. React Kinet Catal Lett 83: 229-236. 